\title{
The chromium isotope composition of reducing and oxic marine sediments
}

Bleuenn Gueguen ${ }^{1, *}$, Christopher T. Reinhard ${ }^{2}$, Thomas J. Algeo ${ }^{3}$, Larry C. Peterson ${ }^{4}$, Sune G. Nielsen ${ }^{5}$, Xiangli Wang ${ }^{1}$, Harry Rowe ${ }^{6}$, Noah J. Planavsky ${ }^{1}$

${ }^{1}$ Department of Geology and Geophysics, Yale University, New Haven, CT 06520, USA

${ }^{2}$ School of Earth and Atmospheric Sciences, Georgia Institute of Technology, Atlanta, GA 30332, USA

${ }^{3}$ Department of Geology, University of Cincinnati, Cincinnati, OH 45221, USA

${ }^{4}$ Rosenstiel School of Marine and Atmospheric Science, Marine Geosciences, University of Miami, Miami, FL 33149, USA

${ }^{5}$ Department of Geology and Geophysics, Woods Hole Oceanographic Institution, Woods Hole, MA 02543, USA

${ }^{6}$ Bureau of Economic Geology, The University of Texas at Austin, University Station, Box X Austin, TX 78713-8924, USA

Revised manuscript submitted to Geochimica et Cosmochimica Acta

* Corresponding author 


\section{Abstract}

The chromium $(\mathrm{Cr})$ isotope composition of marine sediments has the potential to provide new insights into the evolution of Earth-surface redox conditions. There are significant but poorly constrained isotope fractionations associated with oxidative subaerial weathering and riverine transport, the major source of seawater $\mathrm{Cr}$, and with partial $\mathrm{Cr}$ reduction during burial in marine sediments, the major sink for seawater Cr. A more comprehensive understanding of these processes is needed to establish global $\mathrm{Cr}$ isotope mass balance and to gauge the utility of $\mathrm{Cr}$ isotopes as a paleoredox proxy. For these purposes, we investigated the $\mathrm{Cr}$ isotope composition of reducing sediments from the upwelling zone of the Peru Margin and the deep Cariaco Basin. Chromium is present in marine sediments in both detrital and authigenic phases, and to estimate the isotopic composition of the authigenic fraction, we measured $\delta^{53} \mathrm{Cr}$ on a weakly acid-leached fraction in addition to the bulk sediment. In an effort to examine potential variability in the $\mathrm{Cr}$ isotope composition of the detrital fraction, we also measured $\delta^{53} \mathrm{Cr}$ on a variety of oxic marine sediments that contain minimal authigenic $\mathrm{Cr}$. The average $\delta^{53} \mathrm{Cr}$ value of the oxic sediments examined here is $-0.05 \pm 0.10 \%$ o $(2 \sigma, \mathrm{n}=25)$, which is within the range of $\delta^{53} \mathrm{Cr}$ values characteristic of the bulk silicate Earth. This implies that uncertainty in estimates of authigenic $\delta^{53} \mathrm{Cr}$ values based on bulk sediment analyses is mainly linked to estimation of the ratio of $\mathrm{Cr}$ in detrital versus authigenic phases, rather than to the Cr-isotopic composition of the detrital pool. Leaches of Cariaco Basin sediments have an average $\delta^{53} \mathrm{Cr}$ value of $+0.38 \pm 0.10 \%(2 \sigma, \mathrm{n}=7)$, which shows no dependency on sample location within the basin and is close to that of Atlantic deepwater $\mathrm{Cr}(\sim+0.5 \%)$. This suggests that authigenic $\mathrm{Cr}$ in anoxic sediments may reliably reflect the first-order $\mathrm{Cr}$ isotope composition of deepwaters. For Peru Margin samples, the average $\delta^{53} \mathrm{Cr}$ values of bulk sediments $(+0.59 \pm 0.06 \% ; 2 \sigma)$ and leach fractions $(+0.61 \pm 0.06 \%$; $2 \sigma)$ are also comparable with those of Cariaco Basin samples and modern deepwater values. Finally, we found that the 
$\delta^{53} \mathrm{Cr}$ of Peru Margin samples correlates with $\delta^{15} \mathrm{~N}$ on glacial-interglacial timescales, which we attribute to secular variation in basinal or global-ocean redox conditions. Thus, the $\delta^{53} \mathrm{Cr}$ stratigraphic record of Peru Margin sediments indicates that $\mathrm{Cr}$ isotopes may be suited to tracking geologically short-term changes in ocean oxygenation.

\section{Introduction}

Developments in mass spectrometry over the past two decades have given rise to the burgeoning field of 'non-traditional' stable isotope systematics. In particular, isotopic variability associated with the different redox states of transition metals such as Fe, Mo, U and $\mathrm{Cr}$ has catalyzed great interest, and these isotopic systems have been used as biogeochemical tracers in efforts to reconstruct Earth's redox evolution. Despite pioneering work on these isotope systems (see Anbar, 2004; Beard and Johnson, 2004; Schauble, 2004; Anbar and Rouxel, 2007; and references therein), we still lack a comprehensive understanding of the factors controlling the isotopic budget of these elements in Earth's surface environments and in the marine realm. In particular, the chromium $(\mathrm{Cr})$ isotope system has recently emerged as a potentially powerful redox proxy (Frei et al., 2009; Frei et al., 2011; Crowe et al., 2013; Frei et al., 2013; Reinhard et al., 2013; Frei et al., 2014; Planavsky et al., 2014; Reinhard et al., 2014), but there are few Cr isotope studies of modern marine sediments (Bonnand et al., 2013; Reinhard et al., 2014; Pereira et al., 2015).

The marine $\mathrm{Cr}$ cycle is primarily controlled by dissolved/particulate inputs derived from oxidative weathering on the continents and removal of $\mathrm{Cr}$ via authigenic burial in reducing continental margin sediments and anoxic marine basins (Van der Weijden and Reith, 1982; Reinhard et al., 2013). In the continental crust, Cr occurs largely in reduced form as Cr(III) in Cr-rich accessory minerals such as chromite (Fandeur et al., 2009). The initial mobilization of $\mathrm{Cr}$ in soils and further transport of $\mathrm{Cr}$ in aqueous solution requires the 
presence of oxidizing conditions on continental surfaces that make possible the production of soluble $\mathrm{Cr}(\mathrm{VI})$ species during oxidation of insoluble $\mathrm{Cr}(\mathrm{III})$ species. More specifically, the oxidation of $\mathrm{Cr}(\mathrm{III})$ to $\mathrm{Cr}(\mathrm{VI})$ in modern soils is catalyzed by interaction between $\mathrm{Cr}(\mathrm{III})$ and Mn-oxide phases $\left(\mathrm{MnO}_{2}\right)$ (Bartlett and James, 1979; Eary and Rai, 1987; Fendorf, 1995; Oze et al., 2007). Oxidation of $\mathrm{Cr}$ (III) to $\mathrm{Cr}$ (VI) results in the formation of very soluble chromate oxyanion species $\left(\mathrm{HCrO}_{4}^{-}, \mathrm{CrO}_{4}{ }^{2-}\right)$ that are subsequently transported by rivers to the oceans. Upon delivery to the oceans, $\mathrm{Cr}$ is removed from the oceanic pool through burial in reducing environments where reduction of soluble $\mathrm{Cr}(\mathrm{VI}) \mathrm{O}_{4}{ }^{2-}$ to $\mathrm{Cr}(\mathrm{III})$ by a range of reductants results in the partitioning of $\mathrm{Cr}$ into the authigenic fraction of marine sediments. There are reports of significant dissolved $\mathrm{Cr}(\mathrm{III})$ in some riverine systems (e.g., Yusof et al., 2007), but the broad applicability of these observations and long range fate of this $\mathrm{Cr}$ (e.g., in estuaries) are not well constrained. High-temperature and low-temperature (off-axis) hydrothermal systems represent sinks for seawater Cr (Elderfield and Schultz, 1996; Reinhard et al., 2013), but these fluxes are small compared to the riverine flux (i.e., $\sim 0.60 \%$ and $\sim 0.02 \%$ of the riverine flux respectively, Reinhard et al., 2013) suggesting that the influence of hydrothermal systems on the modern isotope mass balance of $\mathrm{Cr}$ is limited.

Much of the recent interest in the $\mathrm{Cr}$ cycle is linked to the view that the isotopic composition of natural $\mathrm{Cr}$ species is governed principally by shifts in redox state - with significant isotopic fractionations expected for both equilibrium exchange between $\mathrm{Cr}$ (III) and $\mathrm{Cr}(\mathrm{VI})$ species and incomplete reduction of $\mathrm{Cr}(\mathrm{VI})$ to $\mathrm{Cr}$ (III) (Schauble et al., 2004; Zink et al., 2010; Wang et al., 2015). However, due to the long timescales of isotopic exchange between $\mathrm{Cr}(\mathrm{III})$ and $\mathrm{Cr}(\mathrm{VI})$ under Earth-surface conditions (e.g., Wang et al., 2015), the isotope systematics of low-temperature $\mathrm{Cr}$ cycling are likely to be dominated by kinetic fractionations associated with partial $\mathrm{Cr}(\mathrm{VI})$ reduction. In any case, both equilibrium and kinetic processes ultimately produce $\mathrm{Cr}(\mathrm{VI})$ that is isotopically heavy (i.e., ${ }^{53} \mathrm{Cr}$-enriched, 
isotopic values are expressed in permil using a delta notation, $\delta^{53} \mathrm{Cr}=$ $\left[\left({ }^{53} \mathrm{Cr} /{ }^{52} \mathrm{Cr}\right)_{\text {sample }} /\left({ }^{53} \mathrm{Cr} /{ }^{52} \mathrm{Cr}\right)_{\text {NIST-979 }}-1\right] \times 1000 \%$ by up to $6 \%$ (Schauble et al., 2004). In marked contrast to other redox tracers such as $\mathrm{Fe}$ or $\mathrm{Mo}, \mathrm{Cr}$ isotope fractionations associated with non-redox-dependent processes such as precipitation of mineral phases (e.g., oxides) or adsorption onto mineral surfaces are currently thought to be negligible (Ellis et al., 2004; Johnson and Bullen, 2004; Schauble et al., 2004). Heavy-isotope $\left({ }^{53} \mathrm{Cr}\right)$ enrichment of the riverine $\mathrm{Cr}$ flux to the oceans relative to upper continental crust (UCC) is indicated both by experimental results and by empirical $\delta^{53} \mathrm{Cr}$ data from South American rivers (from +0.23 and $+0.45 \%$; Frei et al., 2014), Indian river waters (from $+0.67 \%$ and $+1.33 \%$; Paulukat et al., 2015), and global seawater ( +0.5 \%o; Bonnand et al., 2013; Paulukat et al., 2015; Scheiderich et al., 2015).

Significant efforts have been undertaken to better characterize the $\mathrm{Cr}$ isotope composition of modern seawater. Scheiderich et al. (2015) measured the $\delta^{53} \mathrm{Cr}$ of seawater bodies from the Arctic (Beaufort Sea), Pacific, and North Atlantic oceans, as well as seawater samples from the Paraná estuary, and obtained $\delta^{53} \mathrm{Cr}$ values ranging from +0.61 to $+1.55 \%$. The authors attributed this relatively large range of $\mathrm{Cr}$ isotope variation to fractionation during $\mathrm{Cr}(\mathrm{VI})$ reduction to $\mathrm{Cr}(\mathrm{III})$ in surface waters and oxygen minimum zones based on an observed correlation between $\mathrm{Cr}$ concentrations and $\delta^{53} \mathrm{Cr}$ values. They determined an isotope fractionation factor of $-0.80 \%$ during $\mathrm{Cr}(\mathrm{VI})$ reduction to $\mathrm{Cr}(\mathrm{III})$ as inferred from a Rayleigh fractionation model applied to their data. However, studies on the effect of $\mathrm{Cr}$ reduction on $\mathrm{Cr}$ speciation in seawater remain scarce (Elderfield, 1970; Cranston and Murray, 1978; Cranston, 1983; Murray et al., 1983; Rue et al., 1997; Li et al., 2009), and the influence of particles (e.g., scavenging processes) and organic ligands for stabilizing $\mathrm{Cr}$ species in seawater are also poorly documented. In addition, although the reduction of $\mathrm{Cr}(\mathrm{VI})$ in open-ocean $\mathrm{OMZ}$ (oxygen-minimum zone) regions has been observed (Cranston and Murray, 1978; Cranston, 
1983; Murray et al., 1983; Rue et al., 1997), the actual effect of this process on the Cr isotope composition in the water column has not been demonstrated in natural samples. Lastly, the $\mathrm{Cr}$ isotope variation in deep open-ocean seawater is also not well established. Therefore, as emphasized by Scheiderich et al. (2015), more in-depth investigations of $\mathrm{Cr}$ reduction reactions in the water column are needed in order to explore the proposed 'Rayleigh model' for global variations of $\mathrm{Cr}$ isotopes in modern oceans.

Non-quantitative $\mathrm{Cr}$ removal due to partial $\mathrm{Cr}$ reduction, such as in low-oxygen sedimentary depositional environments (with $\mathrm{O}_{2}<5 \mu$ mol. $\mathrm{kg}^{-1}$ and no $\mathrm{H}_{2} \mathrm{~S}$ present) (Rue et al., 1997), may be accompanied by a relatively large $\mathrm{Cr}$ isotope fractionation between bottom waters and authigenic Cr precipitated into the sediment (Reinhard et al., 2014). However, authigenic $\mathrm{Cr}$ in anoxic marine sediments may in some cases approximately capture the $\mathrm{Cr}$ isotope composition of ambient seawater without measurable fractionation provided that uptake is quantitative or nearly so (Reinhard et al., 2014). This is expected to be the case in anoxic water bodies because of rapid reduction of $\mathrm{Cr}(\mathrm{VI}) \mathrm{O}_{4}{ }^{2-}$ by a wide range of natural reductants (Graham and Bouwer, 2012). Authigenic $\mathrm{Cr}$ in marine sediments thus potentially provides a means for tracking seawater $\mathrm{Cr}$ isotope variability through time (assuming limited isotope variability in the globally integrated riverine $\mathrm{Cr}$ flux to the oceans). Although estimates are scarce, $\mathrm{Cr}$ appears to have a shorter residence time ( $\sim 9 \mathrm{kyr}$; Reinhard et al., 2013) than other redox-sensitive trace elements with tractable isotopic systems such as $U$ and Mo ( 800 kyr and 400 kyr; Morford and Emerson, 1999; Dunk et al., 2002). Chromium isotopes are thus potentially sensitive to short-term perturbations (e.g., on the timescales of glacial-interglacial cycles and other relatively rapid geologic events).

Isotopic variation in the Earth-surface $\mathrm{Cr}$ cycle is mainly due to (1) the net effect of processes leading to isotopic fractionation during subaerial weathering and transport of $\mathrm{Cr}$, and (2) partial reduction in reducing marine facies and the integrated mass flux into such 
sediments, the latter of which scales with their spatial distribution in the marine realm. Both temporal fluctuations of redox conditions in modern and ancient environments and the impact of imbalances between the riverine $\mathrm{Cr}$ source flux (i.e., continental oxidative weathering) and the size of the marine reducing sink flux on the oceanic $\mathrm{Cr}$ budget remain poorly constrained at present. However, carbonates and oxic siliciclastic sediments are thought to account for a relatively small fraction of the $\mathrm{Cr}$ sink flux in the oceanic $\mathrm{Cr}$ budget, and the $\mathrm{Cr}$ isotope compositions of these facies are not expected to be strongly fractionated relative to the oceanic pool (Schoenberg et al., 2008; Frei et al., 2011; Bonnand et al., 2013). Further study should lead to an improved understanding of $\mathrm{Cr}$ isotope behavior in marine sediments during sedimentation, burial and post-depositional remobilization, which will be essential for evaluating the factors governing the marine $\mathrm{Cr}$ isotope system.

In the modern oceans, two types of sediment deposited under reducing conditions potentially influence the marine Cr mass balance: (1) sediments deposited in stratified basins with anoxic bottom waters such as the Cariaco Basin and the Black Sea; and (2) sediments deposited in reducing continental margin settings, and in particular along eastern ocean boundaries, where bottom waters may contain some dissolved oxygen but organic carbon fluxes are relatively high and much of the sediment column is reducing. Anoxic sediments of the Cariaco Basin (northern Venezuela, Caribbean Sea) show roughly constant $\mathrm{Cr}$ isotope compositions for most of the last $\sim 14.5 \mathrm{kyr}$ (Reinhard et al., 2014), and $\delta^{53} \mathrm{Cr}$ values corrected for detrital $\mathrm{Cr}$ inputs fall within the range of published Atlantic deepwater values. This observation is consistent with the hypothesis that, in some cases, quantitative $\mathrm{CrO}_{4}{ }^{2-}$ reduction can provide a reliable record of the $\mathrm{Cr}$ isotope composition of ambient seawater.

In contrast to sediments deposited in anoxic basins where contact between dissolved $\mathrm{Cr}(\mathrm{VI})$ and potential reductants is controlled largely by advection and turbulent mixing, reducing continental margin sediments are deposited in bottom waters commonly containing 
small but non-zero amounts of dissolved oxygen. In this case, $\mathrm{CrO}_{4}{ }^{2-}$ reduction may not be quantitative and instead can occur within the sediment below a diffusive boundary layer. This process was described by Reinhard et al. (2014), building on models developed by Bender (1990), Brandes and Devol (1997), and Clark and Johnson (2008). If the depth of oxygen penetration into the sediment is small relative to the reaction-diffusion length scale (i.e., the ratio between the diffusion coefficient of $\mathrm{CrO}_{4}{ }^{2-}$ and the apparent rate constant of a singlestep reduction reaction), partially reduced $\mathrm{Cr}$ can escape from the sediment column, leading to significant $\mathrm{Cr}$ isotope fractionation within the sediment. If diffusional processes dominate the system (i.e., at small oxygen penetration depths), isotopic fractionation should drive the authigenic $\mathrm{Cr}$ towards lighter $\delta^{53} \mathrm{Cr}$ values than the seawater pool. On the other hand, if the diffusive boundary layer is large relative to the reaction-diffusion length scale, reduced $\mathrm{Cr}$ is mostly retained within the sediment, and $\mathrm{Cr}$ isotope fractionation relative to seawater will be minimal. If sediment oxygen penetration dramatically exceeds the reaction-diffusion length scale, reduced $\mathrm{Cr}$ will be mostly retained but authigenic burial fluxes will be very low (e.g., Clark and Johnson, 2008). Thus, both authigenic burial fluxes and Cr isotope fractionation during authigenic enrichment depend strongly on the thickness of the oxygenated sediment layer, a relationship that may be of primary importance in regulating oceanic $\mathrm{Cr}$ isotope mass balance (e.g., Reinhard et al., 2014).

Building on this framework, we conducted a study focusing on: (1) sediments deposited since $\sim 160$ kyr B.P. within the oxygen minimum zone of the Peru Margin, representing an eastern boundary upwelling zone, with the aim of investigating $\mathrm{Cr}$ isotope systematics in reducing continental margin sediments and their potential as an archive for ambient seawater Cr isotope composition; (2) modern core-top sediment samples covering the entire anoxic Cariaco Basin, with the objective of confirming that minimal isotopic fractionation occurs during scavenging of $\mathrm{Cr}$ into authigenic phases in anoxic marine basins; 
and (3) oxic siliciclastic deep-sea sediments from around the globe, with the dual aims of (i) confirming that removal of $\mathrm{Cr}$ into such settings is accompanied by minimal isotopic fractionation and has limited impact on the oceanic $\mathrm{Cr}$ cycle, and (ii) providing constraints on the $\mathrm{Cr}$ isotope composition of a sediment type that dominates modern seafloor deposits.

\section{Geological setting and sample description}

\subsection{Peru Margin}

Samples from the Peru Margin were collected at Site 680 Hole A during Ocean Drilling Program (ODP) Leg 112 (Suess and von Huene, 1988; Dean et al., 1990). The drilling site is located in the Salaverry Basin on the shallow continental shelf of the Peru Margin, and is situated within the OMZ at $\sim 250 \mathrm{~m}$ water depth (Fig. 1a) where oxygen concentrations in bottom waters are $<8.9 \mu \mathrm{mol} . \mathrm{L}^{-1}$. Strong offshore Ekman transport along the western edge of South America leads to coastal upwelling of cold and nutrient-rich waters from the upper thermocline, promoting high levels of surface productivity $\left(>1 \mathrm{gC} \cdot \mathrm{m}^{-2} \cdot \mathrm{day}^{-1}\right)$ along the Peru Margin. Accordingly, seawater column chemistry in this region is characterized by an intense $\mathrm{OMZ}$ that impinges on the continental shelf/slope between $\sim 50$ and $500 \mathrm{~m}$ water depth (Suess and von Huene, 1988). Continental shelf sediments in this area receive a high organic matter flux that results in rapid depletion of oxygen in the sediment column with depth.

Three depositional units have been identified in the three drillcores (A, B, C) from Site 680 (Aplin et al., 1992), but only Units 1 and 3 were recovered in hole A. The samples investigated in this study are entirely from Unit 1 and range from core depths of $0.23 \mathrm{~m}$ to $13.00 \mathrm{~m}$. Sediments of Unit 1 (0-56 m core depth, hole A) are composed of mm- to cm-scale laminated, dark brown-olive diatomaceous muds with elevated organic matter content.

Age control for the Site 680 drillcore is based on oxygen isotope stratigraphy and 
biostratigraphy (Wefer et al., 1990). Oxygen isotope compositions were measured in the benthic foraminifera Bolivina seminuda humilis. Comparison of the $\mathrm{O}$ isotope profile for the study section (Wefer et al., 1990) with the standard marine O-isotope curve from Imbrie et al. (1984) shows consistent results and allows the study section to be accurately dated on this basis. The estimated uncertainties for O-isotope-based dates are $\pm 2.5 \mathrm{kyr}$ (Martinson et al., 1987). Note that recent radiometrically calibrated SPECMAP O-isotope stacks have not appreciably changed the timescale used in this study (Lisiecki and Raymo, 2005; Thompson and Goldstein, 2006).

\subsection{Cariaco Basin}

The Cariaco Basin is located on the northern (Venezuelan) continental shelf of South America and covers a surface area of $\sim 7000 \mathrm{~km}^{2}$ (Fig. 1b), which makes it one of the largest anoxic basins on the modern Earth (Peterson et al., 1991; Scranton et al., 2001; AlveraAzcárate et al., 2009). It consists of two relatively deep sub-basins of $\sim 1400 \mathrm{~m}$ depth separated by a $\sim 900-\mathrm{m}$-deep saddle. Seawater exchange with the Caribbean Sea is limited by the presence of shallow sills on the western (146 m depth) and northern basin margins (120 m depth). Below the mixed surface layer, a strong pycnocline associated with a temperature gradient limits vertical mixing of seawater within the basin itself, restricting ventilation of the deep watermass. Below $\sim 300 \mathrm{~m}$ water depth, the basin is anoxic due to a combination of limited deep water renewal and high surface productivity supplying organic matter that promotes microbial respiration, oxygen depletion, and the accumulation of hydrogen sulfide (e.g., Scranton et al., 2001).

Two depositional units have accumulated in the Cariaco Basin since the Last Glacial Maximum ( $\sim 19$ kyr B.P.). The upper unit consists of finely laminated dark gray to dark green silty clays, whereas the lower unit is composed of yellowish to brownish silty clays lacking 
lamination and showing fine bioturbation. The contact between the two units records an upsection shift from oxic to anoxic conditions in the sediment that occurred at 14.5 kyrs B.P. (Peterson et al., 1991; Dean et al., 1999; Piper and Dean, 2002; Lyons et al., 2003).

The sediment samples investigated in this study were collected during the PLUME-07 cruise that took place in June 1990 on the R/V Thomas Washington (Fig. 1b). A total of 104 cores from different areas of the basin were collected, including piston cores, box cores, and gravity cores. In this study, samples were taken from the uppermost one centimeter of sediment in seven box cores having a wide distribution across the basin. These surface samples can be compared with the long stratigraphic record obtained from the Ocean Drilling Program (ODP) Site 1002 drillcore (Reinhard et al., 2014), which was sampled at depths from $10 \mathrm{~cm}$ to $785 \mathrm{~cm}$ below seafloor. Because the surface fluff layer may have been lost during sampling, the age of the surface sediments is probably a few hundred years.

\subsection{Oxic marine sediments}

We investigated a suite of oxic marine sediments from various regions around the globe (Fig. 1c), with site choices motivated by the aim of constructing a representative $\mathrm{Cr}$ isotope dataset for oxic pelagic surface sediments. Dried sediments were collected from cores housed in the sediment repository of Woods Hole Oceanographic Institution (WHOI). Sediment samples were collected at core depths between 0 and $9 \mathrm{~cm}$, and were drawn from cores taken below $1000 \mathrm{~m}$ water depth, with most samples coming from depths below 3000 $\mathrm{m}$. Sediment lithologies consist predominantly of oxidized fine-grained pelagic clay ranging from light to dark brown or greenish-gray in color, with smaller amounts of calcium carbonate phases and calcareous ooze.

\section{Sample preparation and analytical methods}




\subsection{Elemental concentrations}

Elemental analyses for Peru Margin sediments were performed in the Department of Geology at the University of Cincinnati. Samples were dried in an oven at $80^{\circ} \mathrm{C}$ for 24 hours, ground in an agate ball mill, and stored in plastic vials for later chemical analysis. A wavelength-dispersive Rigaku 3040 X-ray fluorescence (XRF) spectrometer was used for determination of major- and trace-element concentrations on pressed-powder samples. Raw intensities were calibrated with both USGS (SDO-1, SCo-1, SGR-1) and internal black shale standards (analyzed by the commercial company XRAL, X-Ray Assay Laboratories Ltd., Canada). Analytical precision was better than $\pm 2 \%$ for major elements and $\pm 5 \%$ for trace elements, and detection limits were $\sim 1-2 \mathrm{ppm}$ for most trace elements. Total organic carbon (TOC) was determined using an Eltra $2000 \mathrm{C}-\mathrm{S}$ analyzer with results calibrated to USGS and internal laboratory standards. An aliquot of each sample was digested in $1 \mathrm{~N} \mathrm{HCl}$ at $50^{\circ} \mathrm{C}$ for 12 hours and then washed and filtered to remove carbonate carbon prior to analysis. Analytical precision was better than $\pm 2.5 \%$ of reported TOC values.

Major and trace element composition of total digests from Cariaco Basin surface sediments and oxic marine sediments were analyzed by ICP-MS (Element XR, ThermoFinnigan) in the Department of Geology and Geophysics at Yale University using a quartz spray chamber introduction system. An aliquot of the $6 \mathrm{~N} \mathrm{HCl}$ stock solution obtained after total digests (see below) was diluted in $5 \% \mathrm{HNO}_{3}$, and major (Fe, Ti, $\mathrm{Mn}$ ) and trace elements (Cr, Ba, Co, Ni, Cu, Zn, Mo, V, U, Nb, Cd, La, Ce, Tl, Pb, Th) were measured in medium resolution. Measurement precision on raw intensities for major and trace elements was generally better than $\pm 4 \%$ and USGS geostandards BHVO-2 and NOD-A-1 that were processed with samples during each run are within a $\pm 10 \%$ range of reported values.

\subsection{Chromium isotope analyses}


For total digests dried sediments were ashed at $500^{\circ} \mathrm{C}$ for 8 hours to break down organic matter. Ashed samples were then digested using a concentrated $\mathrm{HF}-\mathrm{HNO}_{3}$ mixture followed by aqua regia digestion of dried residues. Final residues were dissolved in $5 \mathrm{ml} 6 \mathrm{~N}$ $\mathrm{HCl}$ for stock solutions.

Chromium isotope compositions were determined for both bulk sediment and leach fractions of samples from the Peru Margin, the Cariaco Basin, and the suite of globally distributed oxic marine sediments. Because the $\mathrm{Cr}$ isotope composition of authigenic phases is likely different from the detrital fraction of $\mathrm{Cr}$, and the latter typically represents a substantial fraction of total $\mathrm{Cr}$ in most siliciclastic marine sediments, it is essential to be able to isolate the authigenic component of the bulk sediment. Our approach was based on a leaching method developed by Reinhard et al. (2014) and previously employed in constructing a downcore Cr isotope record from ODP Site 1002 (Cariaco Basin). Briefly, the authigenic Cr fraction was separated by leaching non-ashed dried sediment with cold $3 \mathrm{~N} \mathrm{HNO}_{3}$ for $\sim 24$ hours.

Chromium isotopes were measured by MC-ICP-MS using a double-spike correction for instrumental mass bias. A mixture of ${ }^{50} \mathrm{Cr}$ and ${ }^{54} \mathrm{Cr}$ isotopes was added to the samples with a constant spike/sample ratio of $\sim 0.5$ prior to $\mathrm{Cr}$ separation on chromatographic columns. The following protocol included three separation steps (Schoenberg et al., 2008; Reinhard et al., 2014) that ensured complete removal of $\mathrm{Fe}$, Ti and V during chemical separation in order to avoid major isobaric interferences of ${ }^{54} \mathrm{Fe},{ }^{50} \mathrm{Ti}$ and ${ }^{50} \mathrm{~V}$ on $\mathrm{Cr}$ isotopes.

In the first step, a split of the $6 \mathrm{~N} \mathrm{HCl}$ stock solution was spiked and evaporated to dryness and residues were taken up in $1 \mathrm{~N} \mathrm{HCl}$. Prior to loading on $2 \mathrm{ml}$ AG1-X8 anionic resin (100-200 mesh) and because only $\mathrm{Cr}(\mathrm{VI})$ is retained on the column, complete oxidation of $\mathrm{Cr}(\mathrm{III})$ to $\mathrm{Cr}(\mathrm{VI})$ was ensured through addition of ammonium persulfate and heating of the samples for 2 hours at $110^{\circ} \mathrm{C}$. AG1-X8 resin was cleaned with mQ water, $3 \mathrm{~N} \mathrm{HNO}_{3}$ and $6 \mathrm{~N}$ 
$\mathrm{HCl}$. The matrix was then eluted with $24 \mathrm{ml}$ of $0.2 \mathrm{~N} \mathrm{HCl}$ and $4 \mathrm{ml} 2 \mathrm{~N} \mathrm{HCl}$, with $\mathrm{Cr}$ subsequently collected with $5 \mathrm{ml} 2 \mathrm{~N} \mathrm{HNO}_{3}$ and $0.5 \% \mathrm{H}_{2} \mathrm{O}_{2}$.

The second step removed traces of Fe that may remain after the first elution. Microcolumns filled with $0.2 \mathrm{ml}$ AG1-X8 resin were cleaned mQ water and $3 \mathrm{~N} \mathrm{HNO}_{3}$, and samples are loaded and collected with $1.2 \mathrm{ml} 6 \mathrm{~N} \mathrm{HCl}$.

In the third step, traces of Ti were removed using a cationic resin AG50W-X8 (200$400 \mathrm{mesh}$ ). The resin was cleaned with $\mathrm{mQ}$ water, $3 \mathrm{~N} \mathrm{HNO}_{3}$ and $6 \mathrm{~N} \mathrm{HCl}$ followed by sample loading in $3 \mathrm{ml} 0.5 \mathrm{~N} \mathrm{HNO}_{3}$ and by matrix elution with $1 \mathrm{ml} 0.5 \mathrm{~N} \mathrm{HNO}_{3}, 2 \mathrm{ml} 0.5 \mathrm{~N} \mathrm{HF}$ and 6

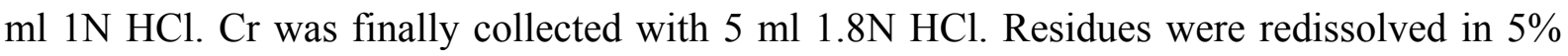
$\mathrm{HNO}_{3}$ for MC-ICP-MS analysis. Chemical yields are generally between $75 \%$ and $85 \%$.

Chromium isotopes were measured on a Neptune Plus (Thermo-Finnigan) MC-ICPMS at Yale University according to the analytical protocol of (Schoenberg et al., 2008; Reinhard et al., 2014). Samples were run in high-resolution mode to resolve polyatomic interferences such as ${ }^{40} \mathrm{Ar}^{12} \mathrm{C}^{+},{ }^{40} \mathrm{Ar}^{14} \mathrm{~N}^{+}$and ${ }^{40} \mathrm{Ar}^{16} \mathrm{O}^{+}$. Although our chemical procedure should ensure complete removal of $\mathrm{Fe}, \mathrm{Ti}$ and $\mathrm{V}$, the presence of these three elements was monitored by measuring ${ }^{56} \mathrm{Fe},{ }^{49} \mathrm{Ti}$ and ${ }^{51} \mathrm{~V}$, which were used to correct our samples for potential interferences of ${ }^{54} \mathrm{Fe}$ on ${ }^{54} \mathrm{Cr}$, and ${ }^{50} \mathrm{Ti}$ and ${ }^{50} \mathrm{~V}$ on ${ }^{50} \mathrm{Cr}$. Standard-sample-bracketing was employed during the analytical session by measuring a spiked $\mathrm{Cr}$ isotope standard NIST SRM 979 before and after each natural sample. Chromium isotope ratios are reported relative to bracketing standards using conventional delta notation $\left(\delta^{53} \mathrm{Cr}=\right.$ $\left[\left({ }^{53} \mathrm{Cr} /{ }^{52} \mathrm{Cr}\right)_{\text {sample }}\left({ }^{53} \mathrm{Cr} /{ }^{52} \mathrm{Cr}\right)_{\text {NIST-979 }}\right.$ - 1] x $\left.1000 \%\right)$. Addition of the double-spike to the samples allowed correction of potential $\mathrm{Cr}$ isotope fractionation during chromatographic separation as well as correction of the instrumental mass bias occurring during introduction of the sample in the mass spectrometer. The double-spike data reduction model is based on the iterative method described by (Siebert et al., 2001). 
External precision is reported as two sigma $(2 \sigma)$ uncertainty, calculated based on duplicate analysis of geological reference materials (GRMs) processed through ion-exchange chromatography columns along with samples (BHVO-2 and Nod-A-1 were systematically processed with 18 samples). The $\delta^{53} \mathrm{Cr}$ value for BHVO-2 is $-0.12 \pm 0.09 \%$ o $(\mathrm{n}=25)$, which is similar to published values in the literature for BHVO-1 (a geostandard collected at the same location as BHVO-2; Schoenberg et al., 2008), and Nod-A-1 yielded a $\delta^{53} \mathrm{Cr}$ value of $0.07 \pm$ $0.09 \%(n=16)$. Sample duplicates including column procedure duplicates, digested duplicates, and replicate measurements on the MC-ICP-MS revealed a $2 \sigma$ uncertainty similar to that determined for GRMs, i.e. $\leq 0.09 \%$ on the reported delta values. Measurement precision is calculated via replicate measurements of the isotopic standard NIST SRM 979 during each analytical session (two standards bracket every sample) and $2 \sigma$ values are better than $0.06 \%$ on the reported delta values. In addition, a two-standard deviation of the mean (2se) is systematically calculated using the 50 cycles of measurement obtained for each sample during MC-ICP-MS analysis and is generally about $0.04 \%$ on the reported delta values.

Chromium in marine sediments is distributed between the detrital component and the authigenic component of the sediment. The $\mathrm{Cr}$ isotope composition of the authigenic fraction can be estimated based on $\mathrm{Cr} / \mathrm{Ti}$ ratios of the bulk sediment and an assumed $\mathrm{Cr} / \mathrm{Ti}$ ratio and $\delta^{53} \mathrm{Cr}$ value for the detrital component. The detrital $\mathrm{Cr} / \mathrm{Ti}$ can be set equal to the average upper continental crust (UCC) ratio of $0.024 \mu \mathrm{g} . \mu \mathrm{g}^{-1}$ (Rudnick and Gao, 2014) or, if possible, estimated from a local detrital baseline, whereas the $\delta^{53} \mathrm{Cr}$ value of the detrital component can be assumed similar to that of the Bulk Silicate Earth (BSE) $\left(\delta^{53} \mathrm{Cr}=-0.124 \pm 0.101 \%\right.$; Schoenber at al., 2008). Using a detrital Cr/Ti ratio (i.e., UCC or local detrital baseline) and $\delta^{53} \mathrm{Cr}$ value of the bulk sediment, the concentration and isotope composition of authigenic $\mathrm{Cr}$ is then calculated by mass balance: 


$$
\delta^{53} \mathrm{Cr}_{\text {bulk sediment }}=\mathrm{f}_{\text {detrital }} \times \delta^{53} \mathrm{Cr}_{\text {detrital }}+\left(1-\mathrm{f}_{\text {detrital }}\right) \times \delta^{53} \mathrm{Cr}_{\text {authigenic }}
$$

where $\mathrm{f}_{\text {detrital }}$ is equal to $(\mathrm{Cr} / \mathrm{Ti})_{\text {detrital }} /(\mathrm{Cr} / \mathrm{Ti})_{\text {sample. }}$ We can then compare $\delta^{53} \mathrm{Cr}$ values measured in leach fractions directly with $\delta^{53} \mathrm{Cr}$ values calculated for the authigenic fractions by mass balance.

\subsection{Nitrogen isotopes}

Nitrogen stable isotopic compositions were determined at the University of Kentucky Environmental Research Training Laboratory. Samples containing $\sim 100 \mu \mathrm{g}$ of nitrogen were weighed into tin capsules and combusted using a Costech 4010 elemental analyzer coupled via a Conflo-III device to a ThermoFinnigan DeltaPlusXP isotope-ratio-mass spectrometer. Nitrogen isotope values are reported as per mille (\%o) variation relative to $\delta^{15} \mathrm{~N}_{\text {air }}$, where $\left.\delta^{15} \mathrm{~N}_{\text {sample }}=\left({ }^{15} \mathrm{~N} /{ }^{14} \mathrm{~N}_{\text {sample }}{ }^{15} \mathrm{~N} /{ }^{14} \mathrm{~N}_{\text {air }}\right)-1\right) \times 1000 \%$. The $\delta^{15} \mathrm{~N}$ of samples was calibrated using three in-house glycine standards that were previously calibrated against international standards. Analytical precision is better than $\pm 0.05 \%$ for reported $\delta^{15} \mathrm{~N}$ values.

\section{Results}

\subsection{Peru Margin}

Geochemical and isotopic results for Peru Margin samples are given in Figure 2 and Table 1a. Total organic content (TOC) displays a large range of values from $\sim 18 \mathrm{wt} \%$ to $\sim 0.7$ $\mathrm{wt} \%$, though most TOC values are $>5 \mathrm{wt} \%$. The highest TOC values are found in the upper sequence during the last $\sim 14 \mathrm{kyr}$. $\mathrm{Cr} / \mathrm{Ti}$ ratios vary from 0.02 to 0.11 but most values are $\sim 0.05$ which is higher than the $\mathrm{Cr} / \mathrm{Ti}$ of $\sim 0.02$ for average UCC (Rudnick and Gao, 2014).

$\delta^{53} \mathrm{Cr}$ values range from $+0.40 \%$ to $+0.91 \%$ in the bulk sediment and from $+0.44 \%$ o to 
$+0.95 \%$ in the leach fractions (Fig. 2d), Cr isotope values in the bulk sediment are essentially indistinguishable from the associated leach fraction as exemplified by similar isotopic patterns. This suggests that the majority of the $\mathrm{Cr}$ in the samples is authigenic, despite a range of $\mathrm{Cr} / \mathrm{Ti}$ ratios and $\mathrm{Cr} / \mathrm{Ti}$ ratios that are sometimes within the range of crustal concentrations, suggesting that $\mathrm{Cr}$ and $\mathrm{Ti}$ can sometimes be decoupled in detrital materials. More specifically this may suggest that the Cr/Ti ratio of detrital materials can be lower (Smith et al., 2013) than typically imagined (e.g., Reinhard et al., 2014). Alternatively, this might suggest that there are detrital $\mathrm{Cr}$ fractions that are liberated in weak acid leaches, which would decrease the $\delta^{53} \mathrm{Cr}$ in the leach. The proportion of clay minerals in the sediment can be as high as $\sim 40 \%$. However, the $\mathrm{Cr}$ present in the detrital fraction is much less soluble in our leaching method than the $\mathrm{Cr}$ in the authigenic phases precipitated within the sediment. The clay-bound $\mathrm{Cr}$ that could also be released during the leaching process is negligible compared to the high amount of authigenic $\mathrm{Cr}$. The release of trace amounts of detrital $\mathrm{Cr}$ and clay-bound $\mathrm{Cr}$ would likely have a negligible impact on the $\mathrm{Cr}$ composition of the leach, which is mostly controlled by release of authigenic $\mathrm{Cr}$. The same is true for the $\mathrm{Cr}$ isotope composition of the bulk sediment, there is likely limited detrital $\mathrm{Cr}$. The $\mathrm{Cr} / \mathrm{Ti}$ ratios in some sediment leachates are reported in Table $1 \mathrm{~b}$.

Comparison of the average $\delta^{53} \mathrm{Cr}$ value for Peru Margin sediments with average deep seawater values (Bonnand et al., 2013; Scheiderich et al., 2015) is not straightforward given the potential for variable seawater values. However, if we take Peru Margin samples deposited within the last $\sim 15 \mathrm{kyr}$, the resulting average values are $\delta^{53} \mathrm{Cr}_{\text {bulk }}=+0.59 \pm 0.03 \%$ o $(2 \sigma)$ and $\delta^{53} \mathrm{Cr}_{\text {leach }}=+0.61 \pm 0.03 \%$ o $(2 \sigma)$, both of which are very well constrained and essentially identical to previously published values from Cariaco Basin Site 1002 (Reinhard et al., 2014). Interestingly, despite being similar to deep Atlantic and Pacific seawater and strikingly invariant, these values are significantly lighter than those of surface seawater from 
the Atlantic Ocean, Pacific Ocean, and Beaufort Sea (Scheiderich et al., 2015).

The Peru Margin $\delta^{53} \mathrm{Cr}$ values are not correlated with variations in enrichment of other redox-sensitive trace elements such as $\mathrm{U}$ and Mo (Fig. 3a-b), or with sediment TOC (Fig. 3c). Variations in $\delta^{53} \mathrm{Cr}$ are also not systematically correlated with variations in authigenic $\mathrm{Cr}$ enrichment (as manifested in variable $\mathrm{Cr} / \mathrm{Ti}$ ratios; Fig. 3d). However, the chromium and nitrogen isotope profiles display significant secular co-variation, with generally higher $\delta^{53} \mathrm{Cr}$ and $\delta^{15} \mathrm{~N}$ corresponding to interglacial intervals and lower $\delta^{53} \mathrm{Cr}$ and $\delta^{15} \mathrm{~N}$ values to glacial intervals (Fig. 2c-d). This covariation is also evident in a roughly linear relationship between $\delta^{53} \mathrm{Cr}$ and $\delta^{15} \mathrm{~N}$ values $\left(\mathrm{R}^{2}=0.66\right.$; and $\mathrm{R}^{2}=0.80$ without the two outliers, Fig. 4$)$.

\subsection{Cariaco Basin}

$\delta^{53} \mathrm{Cr}$ values of the bulk sediment and associated authigenic fractions of the seven core-top samples from the Cariaco Basin investigated in this study are given in Figure 5 and Table 2. For all samples, the isotopic composition of the leach aliquot is substantially ${ }^{53} \mathrm{Cr}$ enriched relative to the corresponding bulk sediment value. The average $\mathrm{Cr}$ isotope composition of the authigenic fraction of the leach aliquot is $+0.38 \pm 0.10 \%$ o $(2 \sigma ; n=7)$, which is in the lower range of previously published values for the Cariaco Basin of +0.58 $\pm 0.10 \%$ and the range of published Atlantic seawater values (Fig. 5), hence most of our Cariaco sites appear to be systematically slightly ${ }^{53} \mathrm{Cr}$-depleted relative to a potential seawater source. Note that surface sediments were not measured for ODP Site 1002 (i.e., measurements start at $\sim 20 \mathrm{cmbsf}$ ). In contrast to Peru Margin sediments, the $\mathrm{Cr}$ isotope composition of Cariaco Basin bulk sediment is lighter with an average of $+0.25 \pm 0.12 \%$ o $(2 \sigma ; n=7)$. Lower $\mathrm{Cr} / \mathrm{Ti}$ ratios of $\sim 0.03$ are consistent with the presence of a higher detrital component in the bulk sediment of the Cariaco Basin compared to the Peru Margin (mean $\mathrm{Cr} / \mathrm{Ti} \sim 0.05$ ) and also with potentially higher detrital $\mathrm{Cr} / \mathrm{Ti}$ ratios in the Cariaco Basin sediments (see discussion). 
Two samples (numbers 4 and 7 in Fig. 5), both located near the northwestern margin of the Cariaco Basin, display slightly lighter $\delta^{53} \mathrm{Cr}$ values for the bulk sediment. There are no other obvious relationships between $\delta^{53} \mathrm{Cr}$ values and sample location, nor is there any significant difference in overall authigenic enrichment of the bulk sediment.

\subsection{Oxic marine sediments}

The average bulk $\delta^{53} \mathrm{Cr}$ value of the globally distributed oxic sediments is $-0.05 \pm$ 0.10\% $(2 \sigma ; \mathrm{n}=25)($ Fig. 6). Crustal $\mathrm{Cr}$ isotope values are observed over a relatively large range of $\mathrm{Cr} / \mathrm{Ti}$ ratios in these samples ( 0.002 to 0.039 ; Table 3$)$. However, over $90 \%$ of these samples have $\mathrm{Cr} / \mathrm{Ti}$ between 0.01 and 0.02 . The $\delta^{53} \mathrm{Cr}$ values measured on the leach fractions of these samples range from -0.21 to $+0.03 \%$ (Table 3 ) and are indistinguishable from the bulk sediment $\delta^{53} \mathrm{Cr}$ values.

\section{Discussion}

\subsection{The Cr isotope composition of oxic deep-ocean sediments and assessment of detrital Cr} isotope variability

For purposes of calculating the isotope composition of the authigenic $\mathrm{Cr}$ component in this study, the detrital component was assumed to have an invariant $\mathrm{Cr} / \mathrm{Ti}$ ratio and $\delta^{53} \mathrm{Cr}$ value equal to those of BSE (Schoenberg et al., 2008). However, the possibility that some isotopic variability exists in the detrital fraction of marine sediments cannot be ruled out. The suite of marine oxic sediments covering most of the oceanic regions of the globe investigated here enables us to directly address this possibility. It has been assumed that there is limited $\mathrm{Cr}$ isotope fractionation between seawater and the oxic and anoxic sinks of chromium (Bonnand et al., 2013; Reinhard et al., 2014). If correct, then the oxic sink should have a negligible influence on temporal fluctuations in seawater $\mathrm{Cr}$ isotope composition. This assumption is 
reasonable based on experimental data showing that $\mathrm{Cr}$ sorption onto $\mathrm{Fe}$ - and Al-oxides (i.e., the primary mineral phases that host $\mathrm{Cr}$ in oxic sediments) is not accompanied by isotope fractionation (Ellis et al., 2004). However, confirmation of this hypothesis via analysis of a range of natural samples is crucial for a full understanding of the $\mathrm{Cr}$ isotope redox proxy framework.

The average $\mathrm{Cr}$ isotope composition of oxic marine sediments $\left(\delta^{53} \mathrm{Cr}=-0.05 \pm\right.$ $0.10 \%, 2 \sigma ; \mathrm{n}=25$; Fig. 6) is slightly heavier than that of the BSE $(-0.124 \pm 0.101 \%$; Schoenberg et al., 2008) and that of high-temperature rocks $(-0.12 \pm 0.13 \%$; Wang et al., 2016) over a large range of $\mathrm{Cr} / \mathrm{Ti}$ ratios (i.e., 0.002 to 0.039 with an average of 0.017 ), but it is still well within the uncertainty range of the latter and similar to the estimated value for the bulk mantle $\mathrm{Cr}(-0.079 \pm 0.129 \%$; Farkaš et al., 2013). Student t-tests indicate that the difference between the mean of oxic sediments and the means of high-temperature rocks and the bulk mantle $\mathrm{Cr}$ is not significant. Reinhard et al. (2014) argued that sediments deposited under oxic conditions in the Cariaco Basin have an average $\mathrm{Cr} / \mathrm{Ti}$ ratio $(\sim 0.021)$ indistinguishable from that of the UCC, which is also similar to the average $\mathrm{Cr} / \mathrm{Ti}$ ratio calculated for the oxic deep-ocean sediments from this study (0.017). Similar $\delta^{53} \mathrm{Cr}$ values in the leach fractions and in the bulk sediment likely indicate a negligible authigenic fraction and dominant detrital fraction of $\mathrm{Cr}$ in the sediment. Our results clearly show a restricted range of $\mathrm{Cr}$ isotope variation in oxic marine sediments, suggesting that (1) removal of marine $\mathrm{Cr}$ to oxic sediments has a negligible influence on the $\mathrm{Cr}$ isotope composition of seawater; and (2) assuming that these sediments contain negligible amounts of authigenic $\mathrm{Cr}$, the $\delta^{53} \mathrm{Cr}$ value of the detrital $\mathrm{Cr}$ component of marine sediments can be assumed to be fairly constant.

5.2. Evaluation of spatial variability in authigenic $\delta^{53} \mathrm{Cr}$ in anoxic marine basins: A case study from the Cariaco Basin 
The Cariaco Basin core-top samples exhibit a range of bulk sediment $\delta^{53} \mathrm{Cr}$ values, with some as heavy as Atlantic seawater values (Bonnand et al., 2013) and others comparatively lighter (e.g., samples 4 and 7 in Fig.5). This variability is somewhat difficult to explain given that all sites are located below the chemocline and exhibit similar sediment chemistry (including $\mathrm{Cr} / \mathrm{Ti}$ ratios). In contrast, the estimated $\delta^{53} \mathrm{Cr}$ values of the authigenic component are remarkably consistent from site to site, with a mean of $+0.38 \pm 0.10 \%$. This suggests that either $\mathrm{Cr}$ isotope fractionation during authigenic uptake in sediments is roughly constant across the basin, or that uptake during reduction is effectively quantitative and fractionations due to partial reduction are minimized (e.g., Reinhard et al., 2014). A more systematic assessment of this pattern and full delineation between these two possibilities awaits detailed measurements of dissolved $\delta^{53} \mathrm{Cr}$ in Cariaco Basin waters.

It is also possible that variations in sedimentation rate and sediment provenance across the Cariaco Basin can account for observed variation in isotopic compositions. Sites 4 and 7, which are both located along the northwestern margin of the basin, can be distinguished on the basis of their bulk sediment $\delta^{53} \mathrm{Cr}$ values, and Site 4 has the lightest authigenic $\delta^{53} \mathrm{Cr}$ value. A potential explanation is that sediments in the northwestern portion of the basin have a somewhat different detrital source, e.g., inputs from Tortuga Island that have a different bulk sediment composition (Yarincik et al., 2000; Martinez et al., 2007; Martinez et al., 2010). It is also possible that the behavior of $\mathrm{Cr}$ and $\mathrm{Ti}$ are decoupled and that some $\mathrm{Cr}$ has been lost from the detrital fraction during transport from its source to the marine environment. This process could produce variable $\mathrm{Cr} / \mathrm{Ti}$ ratios in detrital particles deposited in the Cariaco Basin, which would presumably have proceeded without isotopic fractionation in order to be consistent with the constant $\mathrm{Cr}$ isotope composition of detrital $\mathrm{Cr}$, as reflected in the limited range of values measured in marine oxic sediments. Decoupling of detrital $\mathrm{Cr}$ and $\mathrm{Ti}$ in Cariaco Basin bulk sediments could account for lighter $\delta^{53} \mathrm{Cr}$ values (i.e., $+0.17 \%$ ) for Sites 4 
and 7 in comparison to heavier $\delta^{53} \mathrm{Cr}$ values (i.e., $\sim+0.30 \%$ ) for Sites $1,2,3,5$ and 6 despite similar $\mathrm{Cr} / \mathrm{Ti}$ ratios $(\sim 0.03)$. In this case, Sites 4 and 7 would have a detrital fraction with higher $\mathrm{Cr} / \mathrm{Ti}$ ratios and lower authigenic $\mathrm{Cr}$ enrichment, whereas the opposite would characterize Sites $1,2,3,5$ and 6 . This mechanism remains speculative and additional investigation is needed to clarify whether it applies to our samples. However, despite isotopic variability in the bulk sediment, as discussed above, the estimated authigenic $\delta^{53} \mathrm{Cr}$ values at these sites are nonetheless consistent with those observed elsewhere within the Cariaco Basin.

\subsection{Authigenic Cr in reducing continental margin sediments: the Peru Margin}

The sedimentary succession from the Peru Margin comprises sediments deposited at water depths of $\sim 250 \mathrm{~m}$, which is within the center of the OMZ on the South American continental slope. As a result, this depositional system provides both an interesting contrast to the anoxic Cariaco Basin and a potential record of secular variation in the $\mathrm{Cr}$ isotope composition of Pacific Ocean seawater going back to at least 160 kyr B.P. For this reason, the Cr isotope data from the Peru Margin will be examined both in relation to our Cariaco Basin data and also from the perspective of the chemical evolution of Pacific Ocean seawater through late Quaternary glacial-interglacial cycles.

There are two notable contrasts between the sediment records from the Peru Margin and Cariaco Basin. First, the Peru Margin sediments are significantly more ${ }^{53} \mathrm{Cr}$-enriched than the Cariaco Basin sediments and generally isotopically heavier than published Atlantic and Pacific ocean deepwater values. Second, the $\mathrm{Cr}$ isotope composition of the leach fraction of Peru Margin samples is remarkably similar to that of the bulk sediment in most samples, which is likely mainly a result of the large authigenic $\mathrm{Cr}$ enrichments. In highly productive continental margin settings, the variations of $\mathrm{Cr}$, Mo and $\mathrm{U}$ content of the sediment due to variable redox conditions is generally similar (e.g., Muñoz et al., 2012), so the general lack of 
co-variation between $\delta^{53} \mathrm{Cr}$ values and elemental redox proxies such as Mo and $\mathrm{U}$ in our Peru Margin samples (Fig. 3) indicates that marked shifts in local benthic redox conditions were not a major factor controlling $\delta^{53} \mathrm{Cr}$ values. Therefore, the observed depth trends in $\delta^{53} \mathrm{Cr}$ values are likely to have been caused by variation in the $\mathrm{Cr}$ isotopic composition of either the regional eastern Pacific watermass or the global deep-ocean watermass (see below).

\subsubsection{Preservation of seawater $\mathrm{Cr}$ isotope composition during $\mathrm{Cr}$ removal in reducing} continental margin sediments

Although the range of $\delta^{53} \mathrm{Cr}$ values from +0.40 to $+0.95 \%$ in the Peru Margin is within the range of new $\mathrm{Cr}$ isotope measurements for surface and deep seawater $(+0.44 \%$ o to $+1.55 \%$ ), including North Pacific seawater (Scheiderich et al., 2015), the $\delta^{53} \mathrm{Cr}$ value of the local seawater source of authigenic Cr for Peru Margin sediments is, to our knowledge, not known yet. In this light, it is not possible to determine accurately the potential effect of partial $\mathrm{Cr}$ reduction during $\mathrm{Cr}$ removal from seawater to the sediment. One must also use caution when interpreting $\mathrm{Cr}$ isotope variations in seawater because photo-reduction of $\mathrm{Cr}(\mathrm{VI})$ catalyzed by Fe and organic matter (e.g., phytoplankton) in surface waters (Kieber and Helz, 1992; Connelly et al., 2006; Li et al., 2009) may induce significant $\mathrm{Cr}$ isotope variation in the photic zone, but this process would not be applicable to $\mathrm{Cr}$ isotope variations in deep seawater. Additional work is clearly needed to improve our knowledge of the $\mathrm{Cr}$ isotope composition of modern seawater, particularly for the open-ocean deep watermass.

5.3.2. Relationships between $\delta^{15} N$ and $\delta^{53} C r$ values in reducing continental margin sediments and the link with interglacial/glacial stages

Perhaps the most notable feature of the Peru Margin data is the striking positive correlation between the $\delta^{53} \mathrm{Cr}$ and $\delta^{15} \mathrm{~N}$ profiles (Fig. 4), which appear to track 
interglacial/glacial cycles over the last $160 \mathrm{kyr}$ B.P. (Fig. 2). Nitrogen isotope systematics can potentially provide insight into the controls on $\delta^{53} \mathrm{Cr}$ variations in Peru Margin sediments. The $\delta^{15} \mathrm{~N}$ record from the Peru Margin is broadly consistent with previously inferred changes in the intensity and/or extent of areas of water-column denitrification between glacial and interglacial periods, i.e., lower $\delta^{15} \mathrm{~N}$ during glacial stages and higher $\delta^{15} \mathrm{~N}$ during interglacial stages (Fig. 2c; see Galbraith and Kienast, 2013; Moore et al., 2013). Because sediments deposited in highly productive ocean-margin environments typically record the $\delta^{15} \mathrm{~N}$ of thermocline $\mathrm{NO}_{3}^{-}$(e.g., Thunell et al., 2004), the conventional interpretation of this pattern is that thermocline suboxia was more widespread during interglacial periods. Increases in watercolumn denitrification under extremely low oxygen concentrations will fractionate $\mathrm{N}$ isotopes in nitrate towards heavier $\delta^{15} \mathrm{~N}$ values by up to $20 \%$ (e.g., Galbraith et al., 2008). The isotopically heavy nitrate produced by this process is then transferred to surface waters by upwelling and assimilated by phytoplankton. Ultimately, sinking organic matter will transfer this heavy $\mathrm{N}$ isotope signature to the sediment. Although we consider it premature to definitively link this pattern to a single mechanism, in principle temporal changes in the areal extent or intensity of thermocline suboxia could regulate seawater $\delta^{53} \mathrm{Cr}$ values in one of three ways (none of which are mutually exclusive): (1) expansion/contraction of the seafloor area over which partial Cr reduction operates; (2) changes in the reactively neutral diffusive length scale of continent-margin sediments (see above), e.g., as a result of changes in organic matter flux to the sediment-water interface or bottom water $\mathrm{O}_{2}$ concentrations; or (3) changes in the extent of partial Cr reduction within the water column (analogous to the effect of watercolumn denitrification on $\delta^{15} \mathrm{~N}$ signals). Additional studies on the behavior of $\mathrm{Cr}$ isotopes in the water column (e.g., magnitude of the $\mathrm{Cr}$ isotope fractionation factor), in particular across large OMZs, will help to untangle this issue.

Considerably more data will be needed to establish the presence/absence of significant 
$\mathrm{Cr}$ isotope heterogeneities in the modern oceans and to test potential controls on sediment $\mathrm{Cr}$ isotope compositions in highly productive continent-margin settings. In addition, quantification of the actual $\mathrm{Cr}$ isotope fractionation that could potentially occur during $\mathrm{Cr}$ burial will need to be verified in the future by measuring the $\mathrm{Cr}$ isotope composition of the overlying water column including surface and bottom waters along the Peru Margin. Regardless of these uncertainties, our Peru Margin results suggest that the $\mathrm{Cr}$ isotope system may allow for an independent means to assess changes in ocean oxygenation state on relatively short timescales. This inference is based on the pronounced temporal coherency of the $\delta^{53} \mathrm{Cr}$ profile and its striking relationship with the $\delta^{15} \mathrm{~N}$ record, as well as the short marine residence time of $\mathrm{Cr}(\sim 9 \mathrm{kyr})$ relative to the tempo of glacial-interglacial transitions. Our results thus provide a strong impetus to explore other continent-margin sedimentary $\mathrm{Cr}$ isotope records to improve our understanding of the modern and ancient marine $\mathrm{Cr}$ cycle. The intriguing results of this study will hopefully foster comprehensive investigations of the $\mathrm{Cr}$ isotope cycle in a range of oceanic environments.

\section{Conclusions}

Investigation of the $\mathrm{Cr}$ isotope composition of reducing sediments from the upwelling zone of the Peru Margin and the deep Cariaco Basin and of oxic marine sediments from multiple sites globally provides insights into the marine $\mathrm{Cr}$ cycle. Oxic deep-sea surface sediments yielded a restricted range of $\delta^{53} \mathrm{Cr}$ values $(-0.05 \pm 0.10 \%)$ that are within error of the $\mathrm{Cr}$ isotope composition of average $\mathrm{UCC}$ and BSE. This indicates that, when determining the isotope composition of the authigenic $\mathrm{Cr}$ fraction from bulk marine sediment analyses, the largest current uncertainty is linked to estimates of the proportions of detrital versus

authigenic $\mathrm{Cr}$ rather than to the $\delta^{53} \mathrm{Cr}$ value of detrital $\mathrm{Cr}$ component. Cariaco Basin core-top samples yielded an average $\delta^{53} \mathrm{Cr}$ value $(+0.38 \pm 0.10 \%)$ that is in the lower part of the range 
of previously published $\mathrm{Cr}$ isotope values for Atlantic seawater and the authigenic $\mathrm{Cr}$ fraction of Cariaco Basin Site 1002 sediments. Finally, Peru Margin sediments dating to $<160 \mathrm{kyr}$ B.P. yielded an estimated $\delta^{53} \mathrm{Cr}$ value for the authigenic $\mathrm{Cr}$ component of $+0.61 \pm 0.06 \%$, showing a strong positive correlation between $\delta^{53} \mathrm{Cr}$ values and $\delta^{15} \mathrm{~N}$ values. Our data suggest that intensification or expansion of the oxygen-minimum zone in the oceanic thermocline during interglacial periods may have influenced $\mathrm{Cr}$ isotope fluctuations in seawater, providing a strong impetus for further high-resolution work on the $\delta^{53} \mathrm{Cr}$ composition of reducing continental margin sediments. Coherent downcore $\mathrm{Cr}$ isotope trends at a glacial-interglacial timescale provide strong support for the idea that $\mathrm{Cr}$ isotopes can be used to track short-term seawater redox variations.

\section{Acknowledgments:}

TJA gratefully acknowledges support from the Sedimentary Geology and Paleobiology program of the U.S. National Science Foundation and the NASA Exobiology program, and the China University of Geosciences-Wuhan (program GPMR201301). NJP acknowledges support from the Yale Institute of Biospheric Studies. NJP and CTR acknowledges support from the Alternative Earth's NASA-NAI. We thank the three reviewers for helping to improve the quality of this manuscript. 


\section{References:}

Alvera-Azcárate, A., Barth, A. and Weisberg, R. (2009) A nested model of the Cariaco Basin (Venezuela): description of the basin's interior hydrography and interactions with the open ocean. Ocean Dynamics 59, 97-120.

Anbar, A.D. (2004) Molybdenum Stable Isotopes: Observations, Interpretations and Directions. Reviews in Mineralogy and Geochemistry 55, 429-454.

Anbar, A.D. and Rouxel, O. (2007) Metal stable isotopes in paleoceanography. Annual Review of Earth and Planetary Sciences 35, 717-746.

Aplin, A.C., Bishop, A.N., Clayton, C.J., Kearsley, A.T., Mossmann, J.-R., Patience, R.L., Rees, A.W.G. and Rowland, S.J. (1992) A lamina-scale geochemical and sedimentological study of sediments from the Peru Margin (Site 680, ODP Leg 112). Geological Society, London, Special Publications 64, 131-149.

Bartlett, R. and James, B. (1979) Behavior of Chromium in Soils: III. Oxidation. J. Environ. Qual. 8, 31-35.

Beard, B.L. and Johnson, C.M. (2004) Fe Isotope Variations in the Modern and Ancient Earth and Other Planetary Bodies. Reviews in Mineralogy and Geochemistry 55, 319-357.

Bender, M.L. (1990) The $\delta 180$ of dissolved O2 in seawater: A unique tracer of circulation and respiration in the deep sea. Journal of Geophysical Research: Oceans 95, 22243-22252.

Bonnand, P., James, R.H., Parkinson, I.J., Connelly, D.P. and Fairchild, I.J. (2013) The chromium isotopic composition of seawater and marine carbonates. Earth and Planetary Science Letters 382, 10-20.

Brandes, J.A. and Devol, A.H. (1997) Isotopic fractionation of oxygen and nitrogen in coastal marine sediments. Geochimica et Cosmochimica Acta 61, 1793-1801.

Clark, S.K. and Johnson, T.M. (2008) Effective Isotopic Fractionation Factors for Solute Removal by Reactive Sediments: A Laboratory Microcosm and Slurry Study. Environmental Science \& Technology 42, 7850-7855.

Connelly, D.P., Statham, P.J. and Knap, A.H. (2006) Seasonal changes in speciation of dissolved chromium in the surface Sargasso Sea. Deep Sea Research Part I: Oceanographic Research Papers 53, 1975-1988.

Cranston, R.E. (1983) Chromium in Cascadia Basin, northeast Pacific Ocean. Marine Chemistry 13, 109-125.

Cranston, R.E. and Murray, J.W. (1978) The determination of chromium species in natural waters. Analytica Chimica Acta 99, 275-282.

Crowe, S.A., Dossing, L.N., Beukes, N.J., Bau, M., Kruger, S.J., Frei, R. and Canfield, D.E. (2013) Atmospheric oxygenation three billion years ago. Nature 501, 535-538. 
Dean, W., E.,, Emeis, K.-C., Suess, E. and von Huene, R. (1990) Volume 112 - Scientific Results - Peru Continental Margin. Proceedings of the Ocean Drilling Program, Scientific Results.

Dean, W.E., Piper, D.Z. and Peterson, L.C. (1999) Molybdenum accumulation in Cariaco basin sediment over the past 24 k.y.: A record of water-column anoxia and climate. Geology $27,507-510$.

Dunk, R.M., Mills, R.A. and Jenkins, W.J. (2002) A reevaluation of the oceanic uranium budget for the Holocene. Chemical Geology 190, 45-67.

Eary, L.E. and Rai, D. (1987) Kinetics of chromium(III) oxidation to chromium(VI) by reaction with manganese dioxide. Environmental Science \& Technology 21, 1187-1193.

Elderfield, H. (1970) Chromium speciation in sea water. Earth and Planetary Science Letters 9, 10-16.

Elderfield, H. and Schultz, A. (1996) Mid-ocean ridge hydrothermal fluxes and the chemical composition of the ocean. Annual Review of Earth and Planetary Sciences 24, 191-224.

Ellis, A.S., Johnson, T.M. and Bullen, T.D. (2004) Using Chromium Stable Isotope Ratios To Quantify Cr(VI) Reduction: Lack of Sorption Effects. Environmental Science \& Technology 38, 3604-3607.

Fandeur, D., Juillot, F., Morin, G., Olivi, L., Cognigni, A., Ambrosi, J.-P., Guyot, F. and Fritsch, E. (2009) Synchrotron-based speciation of chromium in an Oxisol from New Caledonia: Importance of secondary Fe-oxyhydroxides. American Mineralogist 94, 710-719.

Farkaš, J., Chrastný, V., Novák, M., Čadkova, E., Pašava, J., Chakrabarti, R., Jacobsen, S.B., Ackerman, L. and Bullen, T.D. (2013) Chromium isotope variations ( $\delta^{53 / 52} \mathrm{Cr}$ ) in mantlederived sources and their weathering products: Implications for environmental studies and the evolution of $\delta{ }^{53 / 52} \mathrm{Cr}$ in the Earth' $\mathrm{s}$ mantle over geologic time. Geochimica Et Cosmochimica Acta 123, 74-92.

Fendorf, S.E. (1995) Surface reactions of chromium in soils and waters. Geoderma 67, 55-71.

Frei, R., Gaucher, C., Døssing, L.N. and Sial, A.N. (2011) Chromium isotopes in carbonates - A tracer for climate change and for reconstructing the redox state of ancient seawater. Earth and Planetary Science Letters 312, 114-125.

Frei, R., Gaucher, C., Poulton, S.W. and Canfield, D.E. (2009) Fluctuations in Precambrian atmospheric oxygenation recorded by chromium isotopes. Nature 461, 250-U125.

Frei, R., Gaucher, C., Stolper, D. and Canfield, D.E. (2013) Fluctuations in late Neoproterozoic atmospheric oxidation - $\mathrm{Cr}$ isotope chemostratigraphy and iron speciation of the late Ediacaran lower Arroyo del Soldado Group (Uruguay). Gondwana Research 23, 797811.

Frei, R., Poiré, D. and Frei, K.M. (2014) Weathering on land and transport of chromium to the ocean in a subtropical region (Misiones, NW Argentina): A chromium stable isotope perspective. Chemical Geology 381, 110-124. 
Galbraith, E.D. and Kienast, M. (2013) The acceleration of oceanic denitrification during deglacial warming. Nature Geosci 6, 579-584.

Galbraith, E.D., Sigman, D.M., Robinson, R.S. and Pedersen, T.F. (2008) Nitrogen in past marine environments. Nitrogen in the marine environment 2, 1497-1535.

Graham, A.M. and Bouwer, E.J. (2012) Oxidative dissolution of pyrite surfaces by hexavalent chromium: Surface site saturation and surface renewal. Geochimica et Cosmochimica Acta 83, 379-396.

Imbrie, J., Hays, J.D., Martinson, D.G., McIntyre, A., Mix, A.C., Morley, J.J., Pisias, N.G., Prell, W.L. and Shackleton, N.J. (1984) The orbital theory of Pleistocene climate: Support from a revised chronology of the marine delta18 O record, Milankovitch and climate: Understanding the response to astronomical forcing, p. 269.

Johnson, T.M. and Bullen, T.D. (2004) Mass-Dependent Fractionation of Selenium and Chromium Isotopes in Low-Temperature Environments. Reviews in Mineralogy and Geochemistry 55, 289-317.

Jouzel, J., Masson-Delmotte, V., Cattani, O., Dreyfus, G., Falourd, S., Hoffmann, G., Minster, B., Nouet, J., Barnola, J.M., Chappellaz, J., Fischer, H., Gallet, J.C., Johnsen, S., Leuenberger, M., Loulergue, L., Luethi, D., Oerter, H., Parrenin, F., Raisbeck, G., Raynaud, D., Schilt, A., Schwander, J., Selmo, E., Souchez, R., Spahni, R., Stauffer, B., Steffensen, J.P., Stenni, B., Stocker, T.F., Tison, J.L., Werner, M. and Wolff, E.W. (2007) Orbital and Millennial Antarctic Climate Variability over the Past 800,000 Years. Science 317, 793-796.

Kieber, R.J. and Helz, G.R. (1992) Indirect photoreduction of aqueous chromium(VI). Environmental Science \& Technology 26, 307-312.

Li, S.-X., Zheng, F.-Y., Hong, H.-S., Deng, N.-s. and Lin, L.-X. (2009) Influence of marine phytoplankton, transition metals and sunlight on the species distribution of chromium in surface seawater. Marine Environmental Research 67, 199-206.

Lisiecki, L.E. and Raymo, M.E. (2005) A Pliocene-Pleistocene stack of 57 globally distributed benthic $\delta 180$ records. Paleoceanography 20, n/a-n/a.

Lyons, T.W., Werne, J.P., Hollander, D.J. and Murray, R.W. (2003) Contrasting sulfur geochemistry and $\mathrm{Fe} / \mathrm{Al}$ and $\mathrm{Mo} / \mathrm{Al}$ ratios across the last oxic-to-anoxic transition in the Cariaco Basin, Venezuela. Chemical Geology 195, 131-157.

Martinez, N.C., Murray, R.W., Thunell, R.C., Peterson, L.C., Muller-Karger, F., Astor, Y. and Varela, R. (2007) Modern climate forcing of terrigenous deposition in the tropics (Cariaco Basin, Venezuela). Earth and Planetary Science Letters 264, 438-451.

Martinez, N.C., Murray, R.W., Thunell, R.C., Peterson, L.C., Muller-Karger, F., Lorenzoni, L., Astor, Y. and Varela, R. (2010) Local and regional geochemical signatures of surface sediments from the Cariaco Basin and Orinoco Delta, Venezuela. Geology 38, 159-162.

Martinson, D.G., Pisias, N.G., Hays, J.D., Imbrie, J., Moore, T.C. and Shackleton, N.J. (1987) Age dating and the orbital theory of the ice ages: Development of a high-resolution 0 to 300,000-year chronostratigraphy. Quaternary Research 27, 1-29. 
Moore, C.M., Mills, M.M., Arrigo, K.R., Berman-Frank, I., Bopp, L., Boyd, P.W., Galbraith, E.D., Geider, R.J., Guieu, C., Jaccard, S.L., Jickells, T.D., La Roche, J., Lenton, T.M., Mahowald, N.M., Maranon, E., Marinov, I., Moore, J.K., Nakatsuka, T., Oschlies, A., Saito, M.A., Thingstad, T.F., Tsuda, A. and Ulloa, O. (2013) Processes and patterns of oceanic nutrient limitation. Nature Geosci 6, 701-710.

Morford, J.L. and Emerson, S. (1999) The geochemistry of redox sensitive trace metals in sediments. Geochimica Et Cosmochimica Acta 63, 1735-1750.

Moynier, F., Yin, Q.-Z. and Schauble, E. (2011) Isotopic Evidence of Cr Partitioning into Earth's Core. Science 331, 1417-1420.

Muñoz, P., Dezileau, L., Lange, C., Cardenas, L., Sellanes, J., Salamanca, M.A. and Maldonado, A. (2012) Evaluation of sediment trace metal records as paleoproductivity and paleoxygenation proxies in the upwelling center off Concepción, Chile $\left(36^{\circ} \mathrm{S}\right)$. Prog. Oceanogr. 92-95, 66-80.

Murray, J., Spell, B. and Paul, B. (1983) The Contrasting Geochemistry of Manganese and Chromium in the Eastern Tropical Pacific Ocean, in: Wong, C.S., Boyle, E., Bruland, K., Burton, J.D., Goldberg, E. (Eds.), Trace Metals in Sea Water. Springer US, pp. 643-669.

Oze, C., Bird, D.K. and Fendorf, S. (2007) Genesis of hexavalent chromium from natural sources in soil and groundwater. Proceedings of the National Academy of Sciences 104, 6544-6549.

Paulukat, C., Døssing, L.N., Mondal, S.K., Voegelin, A.R. and Frei, R. (2015) Oxidative release of chromium from Archean ultramafic rocks, its transport and environmental impact A Cr isotope perspective on the Sukinda valley ore district (Orissa, India). Applied Geochemistry 59, 125-138.

Pereira, N.S., Voegelin, A.R., Paulukat, C., Sial, A.N., Ferreira, V.P. and Frei, R. (2015) Chromium-isotope signatures in scleractinian corals from the Rocas Atoll, Tropical South Atlantic. Geobiology, n/a-n/a.

Peterson, L.C., Overpeck, J.T., Kipp, N.G. and Imbrie, J. (1991) A high-resolution Late Quaternary upwelling record from the anoxic Cariaco Basin, Venezuela. Paleoceanography 6, 99-119.

Piper, D.Z. and Dean, W., E., (2002) Trace-element deposition in the Cariaco Basin, Venezuela Shelf, under sulfate-reducing conditions - a history of the local hydrography and global climate, $20 \mathrm{ka}$ to the Present. USGS Professional Papers 1670, 1-41.

Planavsky, N.J., Reinhard, C.T., Wang, X., Thomson, D., McGoldrick, P., Rainbird, R.H., Johnson, T., Fischer, W.W. and Lyons, T.W. (2014) Low Mid-Proterozoic atmospheric oxygen levels and the delayed rise of animals. Science 346, 635-638.

Reinhard, C.T., Planavsky, N.J., Robbins, L.J., Partin, C.A., Gill, B.C., Lalonde, S.V., Bekker, A., Konhauser, K.O. and Lyons, T.W. (2013) Proterozoic ocean redox and biogeochemical stasis. Proceedings of the National Academy of Sciences of the United States of America 110, 5357-5362. 
Reinhard, C.T., Planavsky, N.J., Wang, X., Fischer, W.W., Johnson, T.M. and Lyons, T.W. (2014) The isotopic composition of authigenic chromium in anoxic marine sediments: A case study from the Cariaco Basin. Earth and Planetary Science Letters 407, 9-18.

Rudnick, R.L. and Gao, S. (2014) Composition of the Continental Crust, in: Holland, H.D., Turekian, K.K. (Eds.), Treatise on Geochemistry (Second Edition). Elsevier, Oxford, pp. 151.

Rue, E.L., Smith, G.J., Cutter, G.A. and Bruland, K.W. (1997) The response of trace element redox couples to suboxic conditions in the water column. Deep Sea Research Part I: Oceanographic Research Papers 44, 113-134.

Schauble, E., Rossman, G.R. and Taylor Jr, H.P. (2004) Theoretical estimates of equilibrium chromium isotope fractionations. Chemical Geology 205, 99-114.

Schauble, E.A. (2004) Applying Stable Isotope Fractionation Theory to New Systems. Reviews in Mineralogy and Geochemistry 55, 65-111.

Scheiderich, K., Amini, M., Holmden, C. and Francois, R. (2015) Global variability of chromium isotopes in seawater demonstrated by Pacific, Atlantic, and Arctic Ocean samples. Earth and Planetary Science Letters 423, 87-97.

Schoenberg, R., Zink, S., Staubwasser, M. and von Blanckenburg, F. (2008) The stable Cr isotope inventory of solid Earth reservoirs determined by double spike MC-ICP-MS. Chemical Geology 249, 294-306.

Scranton, M.I., Astor, Y., Bohrer, R., Ho, T.-Y. and Muller-Karger, F. (2001) Controls on temporal variability of the geochemistry of the deep Cariaco Basin. Deep Sea Research Part I: Oceanographic Research Papers 48, 1605-1625.

Siebert, C., Nagler, T.F. and Kramers, J.D. (2001) Determination of molybdenum isotope fractionation by double-spike multicollector inductively coupled plasma mass spectrometry. Geochemistry Geophysics Geosystems 2, 1032.

Smith, D.B., Cannon, W.F., Woodruff, L.G., Solano, F., Kilburn, J.E. and Fey, D.L. (2013) Geochemical and mineralogical data for soils of the conterminous United States. US Geological Survey Data Series 801, 19.

Suess, E. and von Huene, R. (1988) Ocean Drilling Program Leg 112, Peru continental margin: Part 2, Sedimentary history and diagenesis in a coastal upwelling environment. Geology 16, 939-943.

Thompson, W.G. and Goldstein, S.L. (2006) A radiometric calibration of the SPECMAP timescale. Quaternary Science Reviews 25, 3207-3215.

Thunell, R.C., Sigman, D.M., Muller-Karger, F., Astor, Y. and Varela, R. (2004) Nitrogen isotope dynamics of the Cariaco Basin, Venezuela. Global Biogeochemical Cycles 18, GB3001.

Van der Weijden, C.H. and Reith, M. (1982) Chromium(III) - chromium(VI) interconversions in seawater. Marine Chemistry 11, 565-572. 
Wang, X., Johnson, T.M. and Ellis, A.S. (2015) Equilibrium isotopic fractionation and isotopic exchange kinetics between $\mathrm{Cr}(\mathrm{III})$ and $\mathrm{Cr}(\mathrm{VI})$. Geochimica et Cosmochimica Acta $153,72-90$.

Wang, X., Planavsky, N.J., Reinhard, C.T., Zou, H., Ague, J.J., Wu, Y., Gill, B.C., Schwarzenbach, E.M. and Peucker-Ehrenbrink, B. (2016) Chromium isotope fractionation during subduction-related metamorphism, black shale weathering, and hydrothermal alteration. Chemical Geology 423, 19-33.

Wefer, G., Heinze, P. and Suess, E. (1990) Stratigraphy and sedimentation rates from oxygen isotope composition, organic carbon content, and grain-size distribution at the Peru upwelling region: holes 680B and 686B. Proceedings of the Ocean Drilling Program. Scientific results Chapter 21, 112, 355.

Yarincik, K.M., Murray, R.W. and Peterson, L.C. (2000) Climatically sensitive eolian and hemipelagic deposition in the Cariaco Basin, Venezuela, over the past 578,000 years: Results from Al/Ti and K/Al. Paleoceanography 15, 210-228.

Yusof, A.M., Chia, C.H. and Wood, A.K.H. (2007) Speciation of Cr(III) and Cr(VI) in surface waters with a Chelex-100 resin column and their quantitative determination using inductively coupled plasma mass spectrometry and instrumental neutron activation analysis. J Radioanal Nucl Chem 273, 533-538.

Zink, S., Schoenberg, R. and Staubwasser, M. (2010) Isotopic fractionation and reaction kinetics between $\mathrm{Cr}(\mathrm{III})$ and $\mathrm{Cr}(\mathrm{VI})$ in aqueous media. Geochimica Et Cosmochimica Acta 74, 5729-5745. 


\section{Figure captions:}

Figure 1. Geographical location maps of samples investigated in this study. (a) Location of the Ocean Drilling Program (ODP) Site 680 (red dot) on the Peru continental margin along with positions of other cores collected during the ODP Leg 112; (b) Map of the Cariaco Basin including bathymetric contour lines (meter depth, adapted from Reinhard et al., 2014) showing positions of the core tops represented by colored and numbered symbols (see Table 2 for core info); (c) Map showing locations of oxic marine sediments in global oceans (red circles).

Figure 2. Chemostratigraphic profiles of Peru Margin (Hole 680A) bulk sediment samples showing (a) total organic content (TOC), (b) Cr/Ti ratios, (c) $\mathrm{N}$ isotope composition, and (d) $\mathrm{Cr}$ isotope composition. Transitions between glacial and interglacial periods are specified by horizontal dashed lines. Also shown in (d) is a light grey curve representing variation in Antarctic air temperature reconstructed from the deuterium content of Antarctic ice (Jouzel et al., 2007). The $2 \sigma$ error for $\mathrm{Cr}$ isotope measurements was calculated on replicated measurements of the isotopic standard NIST SRM 979 (see text for more details).

Figure 3. Peru Margin crossplots of the $\mathrm{Cr}$ isotope composition of the bulk sediment (grey circles) and leach fractions (red stars) versus (a) U/Ti ratios, (b) Mo/Ti ratios, (c) TOC, and (d) $\mathrm{Cr} / \mathrm{Ti}$ ratios of the bulk sediment. The lack of correlation between $\mathrm{Cr}$ isotope composition and geochemical proxies for sediment redox conditions indicates a minimal role for variations in local sediment redox conditions in driving $\mathrm{Cr}$ isotope variations. Other details as in Figure 2. 
Figure 4. Peru Margin $\mathrm{Cr}$ isotope composition versus $\mathrm{N}$ isotope composition. Note the positive linear correlation $\left(\mathrm{R}^{2}=0.66\right.$; and $\mathrm{R}^{2}=0.80$ without the two outliers $)$. Other details as in Figure 2.

Figure 5. Chromium isotope composition of bulk sediment (circles) and leach fractions stars) from the Cariaco Basin top core samples. Numbers on the left of sample names refer to sample locations on Figure 1b. The light blue bands represent the range of Atlantic seawater values reported by Bonnand et al. (2013) and Scheiderich et al. (2015) and the ranges of published data for bulk sediment (pink) and leach fractions (purple) from Cariaco Basin are also shown (Reinhard et al., 2014). Other details as in Figure 2.

Figure 6. Histogram of the $\mathrm{Cr}$ isotope values measured in global oxic marine sediments. Also shown are ranges for bulk silicate Earth (BSE; Schoenberg et al., 2008; Farkaš et al., 2013), the bulk Earth model estimate from Moynier et al. (2011), and the range for modern seawater (Bonnand et al., 2013; Scheiderich et al., 2015).

\section{Table captions:}

Table 1a. Peru Margin bulk sediment sample data.

Table 1b. Cr/Ti ratios in Peru Margin sediment leachates.

Table 2. Cariaco Basin bulk sediment sample data.

Table 3. Oxic global marine core-top sediment sample data. 
Table 1a: Peru Margin bulk sediment sample data.

\begin{tabular}{|c|c|c|c|c|c|c|c|c|c|c|c|c|c|c|c|c|}
\hline $\begin{array}{l}\text { Sample } \\
\text { name }\end{array}$ & Units & $1 \mathrm{H} 1-023$ & $1 \mathrm{H} 1-042$ & $1 \mathrm{H} 1-062$ & $1 \mathrm{H} 1-082$ & $1 \mathrm{H} 1-102$ & $1 \mathrm{H} 1-122$ & $1 \mathrm{H} 1-142$ & $1 \mathrm{H} 2-010$ & $1 \mathrm{H} 2-030$ & $1 \mathrm{H} 2-050$ & $1 \mathrm{H} 2-070$ & $1 \mathrm{H} 2-090$ & $1 \mathrm{H} 2-110$ & $1 \mathrm{H} 2-130$ & $1 \mathrm{H} 3-002$ \\
\hline Depth & cmbsf & 23 & 42 & 62 & 82 & 102 & 122 & 142 & 160 & 180 & 200 & 220 & 240 & 260 & 280 & 302 \\
\hline Age & ka & 1.69 & 3.09 & 4.57 & 6.04 & 7.52 & 8.99 & 10.46 & 11.79 & 13.26 & 14.99 & 16.96 & 18.93 & 20.90 & 22.87 & 25.04 \\
\hline$\delta^{15 / 14} \mathrm{~N}$ & $\%$ & 5.23 & $N A^{* *}$ & 6.14 & 5.25 & 5.78 & NA & 6.06 & 5.53 & 4.77 & 5.12 & 4.05 & 6.31 & 6.64 & 3.44 & 0.59 \\
\hline$\delta^{53 / 52} \mathrm{Cr}_{\text {bulk }}$ & $\%$ & 0.57 & 0.59 & 0.57 & 0.55 & 0.63 & 0.64 & 0.60 & 0.59 & 0.56 & 0.65 & 0.72 & 0.73 & 0.73 & 0.64 & 0.57 \\
\hline$\delta^{53 / 52} \mathrm{Cr}_{\text {leach }}{ }^{*}$ & $\%$ & 0.57 & 0.59 & NA & NA & 0.61 & 0.65 & NA & 0.60 & NA & 0.67 & 0.90 & NA & 0.82 & NA & NA \\
\hline $\mathrm{Cr} / \mathrm{Ti}$ & $\mu g \cdot \mu g^{-1}$ & 0.059 & 0.058 & 0.067 & 0.064 & 0.115 & 0.070 & 0.069 & 0.070 & 0.057 & 0.030 & 0.019 & 0.055 & 0.030 & 0.025 & 0.019 \\
\hline $\mathrm{Cr}_{\text {auth }}$ & $\mu g \cdot g^{-1}$ & 66.6 & 62.9 & 60.9 & 149.7 & 69.1 & 73.2 & 81.8 & 72.7 & 64.2 & 0.0 & 0.0 & 63.5 & 0.0 & 0.0 & 0.0 \\
\hline$f_{\text {auth }}$ & - & 0.47 & 0.46 & 0.53 & 0.51 & 0.73 & 0.55 & 0.55 & 0.55 & 0.45 & 0.00 & 0.00 & 0.43 & 0.00 & 0.00 & 0.00 \\
\hline TOC & $w t \%$ & 11.51 & 12.73 & 13.29 & 12.35 & 10.52 & 17.63 & 11.87 & 12.97 & 9.30 & 3.66 & 0.70 & 7.39 & 3.83 & 0.98 & 1.15 \\
\hline $\mathrm{Mg}$ & $\mu \mathrm{g} \cdot \mathrm{g}^{-1}$ & 16,402 & 12,816 & 14,334 & 22,595 & 14,857 & 14,571 & 12,929 & 10,946 & 11,989 & 8,470 & 6,381 & 9,061 & 9,264 & 11,133 & 6,218 \\
\hline Al & $\mu g \cdot g^{-1}$ & 49,148 & 48,299 & 37,659 & 93,992 & 17,859 & 41,903 & 47,028 & 38,439 & 54,439 & 54,909 & 61,316 & 51,367 & 63,779 & 112,708 & 63,912 \\
\hline Mn & $\mu g \cdot g^{-1}$ & 227 & 221 & 185 & 421 & 92 & 186 & 215 & 187 & 223 & 291 & 294 & 269 & 319 & 497 & 291 \\
\hline $\mathrm{Ba}$ & $\mu g \cdot g^{-1}$ & 273 & 460 & 244 & 476 & 243 & 540 & 321 & 807 & 299 & 363 & 414 & 334 & 417 & 1,466 & 442 \\
\hline $\mathrm{Ti}$ & $\mu g \cdot g^{-1}$ & 2,389 & 2,315 & 1,714 & 4,522 & 825 & 1,887 & 2,177 & 1,889 & 2,469 & 2,805 & 2,623 & 2,690 & 3,392 & 4,759 & 2,700 \\
\hline $\mathrm{Cr}$ & $\mu g \cdot g^{-1}$ & 141 & 135 & 115 & 291 & 95 & 132 & 150 & 132 & 141 & 85 & 51 & 148 & 100 & 120 & 52 \\
\hline $\mathrm{Fe}$ & $\mu g \cdot g^{-1}$ & 17,346 & 16,830 & 13,860 & 40,285 & 13,608 & 14,850 & 17,038 & 14,065 & 20,235 & 15,270 & 12,737 & 22,832 & 20,279 & 31,888 & 13,873 \\
\hline Co & $\mu g \cdot g^{-1}$ & 5.6 & 5.7 & 5.1 & 11.3 & 3.0 & 5.7 & 5.9 & 5.1 & 6.1 & 5.1 & 4.3 & 6.5 & 6.1 & 8.5 & 4.7 \\
\hline $\mathrm{Ni}$ & $\mu g \cdot g^{-1}$ & 120 & 126 & 118 & 206 & 93 & 136 & 148 & 135 & 114 & 58 & 23 & 106 & 58 & 44 & 29 \\
\hline $\mathrm{Cu}$ & $\mu g \cdot g^{-1}$ & 95 & 115 & 103 & 148 & 96 & 131 & 118 & 114 & 90 & 34 & 19 & 55 & 39 & 31 & 25 \\
\hline $\mathrm{Zn}$ & $\mu g \cdot g^{-1}$ & 244 & 335 & 100 & 185 & 78 & 117 & 119 & 109 & 117 & 88 & 50 & 97 & 91 & 132 & 59 \\
\hline Mo & $\mu g \cdot g^{-1}$ & 39 & 39 & 50 & 68 & 83 & 79 & 63 & 41 & 33 & 13 & 4 & 65 & 23 & 16 & 15 \\
\hline V & $\mu \mathrm{g} \cdot \mathrm{g}^{-1}$ & 158 & 147 & 203 & 270 & 177 & 242 & 189 & 173 & 141 & 72 & 51 & 131 & 116 & 107 & 59 \\
\hline U & $\mu \mathrm{g} \cdot \mathrm{g}^{-1}$ & 12.9 & 12.2 & 10.2 & 22.6 & 8.1 & 13.5 & 11.3 & 12.2 & 11.6 & 15.4 & 12.0 & 13.2 & 10.6 & 25.1 & 11.6 \\
\hline $\mathrm{Cd}$ & $\mu \mathrm{g} \cdot \mathrm{g}^{-1}$ & 30 & 46 & 74 & 58 & 72 & 100 & 72 & 66 & 46 & 29 & 15 & 37 & 26 & 66 & 24 \\
\hline $\mathrm{Pb}$ & $\mu \mathrm{g} \cdot \mathrm{g}^{-1}$ & 7.3 & 9.8 & 10.7 & 11.8 & 5.8 & 7.8 & 8.3 & 8.4 & 8.3 & 10.2 & 10.1 & 7.9 & 13.8 & 27.9 & 11.7 \\
\hline As & $\mu \mathrm{g} \cdot \mathrm{g}^{-1}$ & 18.6 & 17.1 & 15.2 & 30.7 & 19.6 & 17.1 & 17.9 & 15.8 & 15 & 16.6 & 9.7 & 22.0 & 20.2 & 35.7 & 13.1 \\
\hline $\mathrm{Rb}$ & $\mu g \cdot g^{-1}$ & 64 & 59 & 50 & 111 & 24 & 56 & 58 & 48 & 64 & 57 & 56 & 66 & 73 & 136 & 61 \\
\hline $\mathrm{Sr}$ & $\mu g \cdot g^{-1}$ & 225 & 201 & 342 & 378 & 346 & 250 & 325 & 313 & 350 & 534 & 510 & 256 & 287 & 747 & 464 \\
\hline $\mathrm{Zr}$ & $\mu \mathrm{g} \cdot \mathrm{g}^{-1}$ & 45 & 72 & 22 & 71 & 19 & 27 & 25 & 39 & 35 & 47 & 40 & 48 & 55 & 68 & 51 \\
\hline w & $\mu \mathrm{g} \cdot \mathrm{g}^{-1}$ & 1.3 & 1.4 & 1.4 & 2.3 & 1.3 & 1.3 & 1.3 & 1.2 & 1.4 & 1.3 & 1.1 & 1.4 & 1.2 & 1.7 & 1.0 \\
\hline
\end{tabular}

${ }^{*}$ Cr isotope composition measured in the leach fraction.

${ }^{\star *} \mathrm{NA}$ : not analyzed. 


\begin{tabular}{|c|c|c|c|c|c|c|c|c|c|c|c|c|c|c|c|c|}
\hline $\begin{array}{l}\text { Sample } \\
\text { name }\end{array}$ & Units & $1 \mathrm{H} 3-022$ & $1 \mathrm{H} 3-042$ & $1 \mathrm{H} 3-062$ & $1 \mathrm{H} 3-082$ & $1 \mathrm{H} 3-102$ & $1 \mathrm{H} 3-122$ & $1 \mathrm{H} 3-142$ & $1 \mathrm{H} 4-010$ & $1 \mathrm{H} 4-030$ & $1 \mathrm{H} 4-050$ & $1 \mathrm{H} 4-070$ & $1 \mathrm{H} 4-090$ & $1 \mathrm{H} 4-110$ & $1 \mathrm{H} 4-130$ & $1 \mathrm{H} 5-002$ \\
\hline Depth & cmbsf & 322 & 342 & 362 & 382 & 402 & 422 & 442 & 460 & 480 & 500 & 520 & 540 & 560 & 580 & 602 \\
\hline Age & ka & 27.01 & 29.38 & 32.13 & 34.88 & 37.63 & 40.39 & 43.14 & 45.61 & 48.37 & 51.12 & 53.87 & 56.62 & 58.86 & 60.57 & 62.46 \\
\hline$\delta^{15 / 4} \mathrm{~N}$ & $\%$ & 1.03 & 3.48 & 3.37 & 2.90 & 3.90 & 4.00 & 3.19 & 3.91 & 3.17 & 3.85 & 3.54 & 4.19 & 3.73 & 2.97 & 2.94 \\
\hline$\delta^{53 / 52} \mathrm{Cr}_{\text {bulk }}$ & $\%$ & NA & NA & 0.42 & NA & 0.52 & 0.53 & 0.44 & NA & NA & 0.46 & NA & 0.52 & NA & NA & 0.40 \\
\hline$\delta^{53 / 52} \mathrm{Cr}_{\text {leach }}$ & $\%$ & NA & NA & 0.48 & NA & 0.50 & NA & NA & NA & NA & 0.47 & NA & NA & NA & NA & 0.48 \\
\hline $\mathrm{Cr} / \mathrm{Ti}$ & $\mu \mathrm{g} \cdot \mu \mathrm{g}^{-1}$ & 0.017 & 0.029 & 0.033 & 0.036 & 0.048 & 0.055 & 0.035 & 0.042 & 0.041 & 0.043 & 0.043 & 0.059 & 0.043 & 0.038 & 0.037 \\
\hline $\mathrm{Cr}_{\text {auth }}$ & $\mu g \cdot g^{-1}$ & 0.0 & 0.0 & 3.8 & 11.7 & 37.0 & 49.3 & 11.1 & 27.4 & 28.3 & 27.9 & 28.3 & 37.1 & 26.0 & 19.5 & 14.3 \\
\hline$f_{\text {auth }}$ & - & 0.00 & 0.00 & 0.04 & 0.12 & 0.35 & 0.44 & 0.11 & 0.26 & 0.23 & 0.27 & 0.28 & 0.47 & 0.27 & 0.17 & 0.15 \\
\hline TOC & $w t \%$ & 0.82 & 4.41 & 5.67 & 4.99 & 6.39 & 7.20 & 5.34 & 5.41 & 7.35 & 7.35 & 5.53 & 8.67 & 6.41 & 5.56 & 6.31 \\
\hline Mg & $\mu \mathrm{g} \cdot \mathrm{g}^{-1}$ & 10,287 & 9,189 & 10,128 & 10,502 & 10,752 & 9,868 & 11,060 & 11,297 & 11,151 & 10,427 & 9,821 & 8,985 & 8,885 & 12,450 & 8,691 \\
\hline Al & $\mu \mathrm{g} \cdot \mathrm{g}^{-1}$ & 94,392 & 56,368 & 52,617 & 55,921 & 46,795 & 41,556 & 56,058 & 52,690 & 56,770 & 49,088 & 46,942 & 28,146 & 44,165 & 63,859 & 47,107 \\
\hline Mn & $\mu g \cdot g^{-1}$ & 479 & 313 & 290 & 297 & 271 & 237 & 300 & 284 & 300 & 278 & 248 & 161 & 242 & 326 & 266 \\
\hline $\mathrm{Ba}$ & $\mu g \cdot g^{-1}$ & 623 & 1,356 & 316 & 324 & 306 & 276 & 304 & 401 & 305 & 292 & 290 & 219 & 273 & 304 & 268 \\
\hline $\mathrm{Ti}$ & $\mu \mathrm{g} \cdot \mathrm{g}^{-1}$ & 4,118 & 2,970 & 2,723 & 2,765 & 2,221 & 2,039 & 2,919 & 2,495 & 2,992 & 2,390 & 2,385 & 1,341 & 2,286 & 3,133 & 2,539 \\
\hline $\mathrm{Cr}$ & $\mu \mathrm{g} \cdot \mathrm{g}^{-1}$ & 72 & 87 & 89 & 98 & 106 & 113 & 102 & 105 & 122 & 103 & 103 & 79 & 97 & 117 & 94 \\
\hline $\mathrm{Fe}$ & $\mu \mathrm{g} \cdot \mathrm{g}^{-1}$ & 24,996 & 22,424 & 19,240 & 22,248 & 18,793 & 19,010 & 21,517 & 20,412 & 22,670 & 19,520 & 17,537 & 13,249 & 18,222 & 23,533 & 18,043 \\
\hline Co & $\mu g \cdot g^{-1}$ & 7.2 & 6.3 & 5.7 & 6.1 & 6.2 & 6.1 & 6.4 & 6.4 & 7.1 & 6.3 & 5.9 & 4.1 & 5.8 & 7.9 & 5.9 \\
\hline $\mathrm{Ni}$ & $\mu \mathrm{g} \cdot \mathrm{g}^{-1}$ & 36 & 63 & 57 & 42 & 87 & 94 & 65 & 80 & 79 & 72 & 75 & 78 & 82 & 76 & 70 \\
\hline $\mathrm{Cu}$ & $\mu \mathrm{g} \cdot \mathrm{g}^{-1}$ & 37 & 65 & 57 & 79 & 121 & 102 & 90 & 64 & 71 & 74 & 63 & 70 & 102 & 65 & 56 \\
\hline $\mathrm{Zn}$ & $\mu \mathrm{g} \cdot \mathrm{g}^{-1}$ & 89 & 100 & 102 & 121 & 118 & 112 & 115 & 114 & 119 & 107 & 100 & 81 & 115 & 115 & 100 \\
\hline Mo & $\mu g \cdot g^{-1}$ & 25 & 37 & 28 & 46 & 40 & 44 & 35 & 49 & 42 & 42 & 39 & 48 & 45 & 32 & 28 \\
\hline v & $\mu g \cdot g^{-1}$ & 95 & 111 & 113 & 116 & 143 & 135 & 123 & 157 & 151 & 134 & 140 & 121 & 159 & 154 & 118 \\
\hline U & $\mu \mathrm{g} \cdot \mathrm{g}^{-1}$ & 14.2 & 9.5 & 7.7 & 8.5 & 9.8 & 9.5 & 9.3 & 8.2 & 10.8 & 8.5 & 9.6 & 7.1 & 9.6 & 10.1 & 9.3 \\
\hline $\mathrm{Cd}$ & $\mu \mathrm{g} \cdot \mathrm{g}^{-1}$ & 27 & 36 & 34 & 7 & 47 & 50 & 39 & 37 & 45 & 42 & 44 & 60 & 47 & 18 & 23 \\
\hline $\mathrm{Pb}$ & $\mu g \cdot g^{-1}$ & 16.3 & 10.4 & 8.2 & 11.8 & 9.9 & 7.6 & 9.9 & 11.9 & 12.5 & 12.0 & 9.9 & 8.3 & 8.9 & 11.6 & 11.1 \\
\hline As & $\mu \mathrm{g} \cdot \mathrm{g}^{-1}$ & 32.1 & 24.2 & 17.1 & 17.1 & 15.9 & 19.0 & 18.8 & 16.7 & 18.9 & 18.2 & 11.8 & 14.6 & 14.0 & 12.3 & 11.0 \\
\hline $\mathbf{R b}$ & $\mu \mathrm{g} \cdot \mathrm{g}^{-1}$ & 84 & 70 & 73 & 80 & 63 & 59 & 71 & 79 & 74 & 66 & 65 & 43 & 60 & 81 & 60 \\
\hline $\mathrm{Sr}$ & $\mu \mathrm{g} \cdot \mathrm{g}^{-1}$ & 594 & 328 & 298 & 197 & 268 & 218 & 291 & 212 & 336 & 350 & 436 & 273 & 267 & 249 & 346 \\
\hline $\mathrm{Zr}$ & $\mu \mathrm{g} \cdot \mathrm{g}^{-1}$ & 67 & 53 & 40 & 30 & 42 & 28 & 38 & 29 & 44 & 41 & 30 & 15 & 30 & 40 & 42 \\
\hline w & $\mu \mathrm{g} \cdot \mathrm{g}^{-1}$ & 1.6 & 1.4 & 1.1 & 1.3 & 13.9 & 1.5 & 1.4 & 1.2 & 1.4 & 1.2 & 1.1 & 0.7 & 1.6 & 1.2 & 1.4 \\
\hline
\end{tabular}




\begin{tabular}{|c|c|c|c|c|c|c|c|c|c|c|c|c|c|c|c|c|}
\hline \begin{tabular}{|l|}
$\begin{array}{l}\text { Sample } \\
\text { name }\end{array}$ \\
\end{tabular} & Units & $1 \mathrm{H} 5-020$ & $1 \mathrm{H} 5-040$ & $1 \mathrm{H} 5-062$ & $1 \mathrm{H} 5-080$ & $1 \mathrm{H} 5-100$ & $1 \mathrm{H} 5-120$ & $1 \mathrm{H} 5-140$ & $1 \mathrm{H} 6-010$ & $1 \mathrm{H} 6-032$ & $1 \mathrm{H} 6-050$ & $1 \mathrm{HCCW}-14$ & $2 \mathrm{H} 1-010$ & $2 \mathrm{H} 1-030$ & $2 \mathrm{H} 1-050$ & $2 \mathrm{H} 1-070$ \\
\hline Depth & cmbsf & 620 & 640 & 662 & 680 & 700 & 720 & 740 & 760 & 782 & 800 & 825 & 835 & 855 & 875 & 895 \\
\hline Age & ka & 64.00 & 65.71 & 67.60 & 69.14 & 71.64 & 74.93 & 78.22 & 81.51 & 85.12 & 88.08 & 92.19 & 93.84 & 97.12 & 100.41 & 103.70 \\
\hline$\delta^{15 / 14} \mathrm{~N}$ & $\%$ & 3.36 & 3.80 & 4.27 & 3.18 & 3.35 & 3.62 & 3.68 & 6.12 & 7.63 & 7.19 & 7.51 & 7.23 & 4.48 & 6.99 & 8.07 \\
\hline$\delta^{53 / 52} \mathrm{Cr}_{\text {bulk }}$ & $\%$ & 0.47 & NA & NA & 0.42 & NA & NA & 0.55 & 0.75 & 0.80 & 0.75 & 0.88 & 0.83 & 0.67 & 0.74 & NA \\
\hline$\delta^{53 / 52} \mathrm{Cr}_{\text {leach }}$ & $\%$ & 0.44 & NA & NA & NA & NA & NA & NA & 0.76 & NA & NA & 0.90 & NA & NA & NA & NA \\
\hline $\mathrm{Cr} / \mathrm{Ti}$ & $\mu \mathrm{g} \cdot \mu \mathrm{g}^{-1}$ & 0.057 & 0.047 & 0.064 & 0.037 & 0.051 & 0.060 & 0.046 & 0.090 & 0.086 & 0.087 & 0.081 & 0.065 & 0.049 & 0.053 & 0.062 \\
\hline $\mathrm{Cr}_{\text {auth }}$ & $\mu g \cdot g^{-1}$ & 55.4 & 33.5 & 79.2 & 28.5 & 51.4 & 67.3 & 37.4 & 117.1 & 90.5 & 95.8 & 61.8 & 69.4 & 41.1 & 47.7 & 60.9 \\
\hline$f_{\text {auth }}$ & - & 0.45 & 0.34 & 0.51 & 0.15 & 0.39 & 0.48 & 0.31 & 0.65 & 0.64 & 0.64 & 0.61 & 0.52 & 0.36 & 0.41 & 0.50 \\
\hline TOC & wt $\%$ & 8.27 & 6.38 & 9.09 & 6.68 & 10.00 & 11.29 & 5.45 & 8.27 & 10.82 & 8.57 & 5.89 & 10.00 & 6.83 & 5.82 & 5.78 \\
\hline $\mathrm{Mg}$ & $\mu \mathrm{g} \cdot \mathrm{g}^{-1}$ & 9,473 & 9,370 & 16,785 & 17,657 & 10,157 & 10,213 & 9,802 & 11,042 & 12,402 & 11,215 & 10,359 & 10,788 & 9,628 & 11,801 & 11,264 \\
\hline Al & $\mu \mathrm{g} \cdot \mathrm{g}^{-1}$ & 44,529 & 41,982 & 50,236 & 98,651 & 49,587 & 46,933 & 50,138 & 43,240 & 38,075 & 38,708 & 26,458 & 44,465 & 47,090 & 49,111 & 42,722 \\
\hline Mn & $\mu g \cdot g^{-1}$ & 240 & 235 & 261 & 508 & 250 & 242 & 278 & 277 & 225 & 230 & 181 & 271 & 264 & 289 & 264 \\
\hline $\mathrm{Ba}$ & $\mu g \cdot g^{-1}$ & 251 & 252 & 478 & 572 & 314 & 299 & 311 & 413 & 403 & 436 & 9,185 & 369 & 314 & 432 & 2,165 \\
\hline $\mathrm{Ti}$ & $\mu g \cdot g^{-1}$ & 2,152 & 2,069 & 2,391 & 5,143 & 2,621 & 2,338 & 2,602 & 2,007 & 1,645 & 1,719 & 1,242 & 2,053 & 2,359 & 2,189 & 1,954 \\
\hline $\mathrm{Cr}$ & $\mu \mathrm{g} \cdot \mathrm{g}^{-1}$ & 123 & 98 & 154 & 189 & 133 & 140 & 119 & 180 & 142 & 150 & 101 & 134 & 115 & 116 & 122 \\
\hline $\mathrm{Fe}$ & $\mu \mathrm{g} \cdot \mathrm{g}^{-1}$ & 16,541 & 15,886 & 18,722 & 36,321 & 17,604 & 17,471 & 17,241 & 17,038 & 15,712 & 15,240 & 10,959 & 17,470 & 17,297 & 19,728 & 17,547 \\
\hline Co & $\mu \mathrm{g} \cdot \mathrm{g}^{-1}$ & 5.4 & 5.2 & 6.8 & 12.7 & 6.0 & 5.7 & 5.9 & 7.2 & 7.4 & 6.2 & 4.4 & 6.6 & 6.0 & 7.0 & 6.2 \\
\hline $\mathrm{Ni}$ & $\mu \mathrm{g} \cdot \mathrm{g}^{-1}$ & 96 & 77 & 157 & 152 & 105 & 122 & 88 & 162 & 141 & 153 & 86 & 112 & 95 & 95 & 79 \\
\hline $\mathrm{Cu}$ & $\mu \mathrm{g} \cdot \mathrm{g}^{-1}$ & 70 & 60 & 109 & 116 & 72 & 60 & 59 & 91 & 124 & 81 & 63 & 67 & 99 & 106 & 98 \\
\hline Zn & $\mu \mathrm{g} \cdot \mathrm{g}^{-1}$ & 102 & 117 & 162 & 208 & 111 & 149 & 99 & 94 & 95 & 91 & 80 & 90 & 102 & 104 & 99 \\
\hline Mo & $\mu \mathrm{g} \cdot \mathrm{g}^{-1}$ & 41 & 44 & 82 & 56 & 31 & 43 & 33 & 62 & 86 & 99 & 75 & 54 & 50 & 55 & 65 \\
\hline v & $\mu \mathrm{g} \cdot \mathrm{g}^{-1}$ & 142 & 151 & 243 & 264 & 137 & 152 & 118 & 255 & 261 & 318 & 241 & 230 & 156 & 272 & 266 \\
\hline u & $\mu g \cdot g^{-1}$ & 11.2 & 9.5 & 17.4 & 19.7 & 14.7 & 12.4 & 15.7 & 15.6 & 15.7 & 14.0 & 6.4 & 13.0 & 12.6 & 12.7 & 13.6 \\
\hline Cd & $\mu \mathrm{g} \cdot \mathrm{g}^{-1}$ & 35 & 43 & 110 & 48 & 28 & 63 & 44 & 71 & 72 & 77 & 77 & 61 & 40 & 44 & 69 \\
\hline $\mathrm{Pb}$ & $\mu \mathrm{g} \cdot \mathrm{g}^{-1}$ & 9.9 & 11.0 & 16.6 & 21.6 & 10.7 & 10.6 & 11.2 & 8.0 & 10.5 & 12.1 & 12.3 & 9.1 & 39.5 & 11.7 & 10.2 \\
\hline As & $\mu \mathrm{g} \cdot g^{-1}$ & 13.2 & 13.4 & 20.5 & 19.6 & 11.2 & 12.2 & 12.3 & 12.0 & 13.7 & 16.8 & 12.2 & 14.7 & 12.9 & 16.7 & 16.4 \\
\hline $\mathbf{R b}$ & $\mu \mathrm{g} \cdot \mathrm{g}^{-1}$ & 60 & 56 & 72 & 116 & 64 & 61 & 58 & 53 & 44 & 47 & 39 & 61 & 57 & 60 & 54 \\
\hline Sr & $\mu \mathrm{g} \cdot \mathrm{g}^{-1}$ & 313 & 392 & 839 & 518 & 440 & 360 & 513 & 305 & 416 & 353 & 613 & 368 & 382 & 418 & 412 \\
\hline $\mathrm{Zr}$ & $\mu \mathrm{g} \cdot \mathrm{g}^{-1}$ & 23 & 21 & 38 & 72 & 41 & 30 & 40 & 27 & 39 & 33 & 24 & 28 & 44 & 32 & 45 \\
\hline w & $\mu \mathrm{g} \cdot \mathrm{g}^{-1}$ & 1.1 & 12.4 & 1.4 & 2.4 & 1.2 & 1.2 & 1.1 & 1.8 & 0.7 & 0.8 & 0.9 & 0.9 & 1.0 & 1.3 & 1.1 \\
\hline
\end{tabular}




\begin{tabular}{|c|c|c|c|c|c|c|c|c|c|c|c|c|c|c|c|c|c|c|c|}
\hline $\begin{array}{l}\text { Sample } \\
\text { name }\end{array}$ & Units & $2 \mathrm{H} 1-090$ & $2 \mathrm{H} 1-110$ & $2 \mathrm{H} 1-130$ & $2 \mathrm{H} 2-002$ & $2 \mathrm{H} 2-020$ & $2 \mathrm{H} 2-040$ & $2 \mathrm{H} 2-060$ & $2 \mathrm{H} 2-080$ & $2 \mathrm{H} 2-100$ & $2 \mathrm{H} 2-120$ & $2 \mathrm{H} 2-140$ & $2 \mathrm{H} 3-010$ & $2 \mathrm{H} 3-030$ & $2 \mathrm{H} 3-050$ & $2 \mathrm{H} 3-070$ & $2 \mathrm{H} 3-090$ & $2 \mathrm{H} 3-110$ & $2 \mathrm{H} 3-130$ \\
\hline Depth & cmbsf & 915 & 935 & 955 & 977 & 995 & 1015 & 1035 & 1055 & 1075 & 1095 & 1115 & 1135 & 1155 & 1175 & 1195 & 1215 & 1235 & 1255 \\
\hline Age & ka & 106.99 & 110.27 & 113.56 & 117.18 & 120.14 & 123.42 & 126.71 & 130.00 & 133.00 & 136.00 & 139.00 & 142.00 & 145.00 & 148.00 & 151.00 & 154.00 & 157.00 & 160.00 \\
\hline$\delta^{15 / 4} \mathrm{~N}$ & $\%$ & 8.30 & 8.80 & 9.17 & 9.34 & 8.74 & 6.95 & 8.06 & 7.03 & 7.03 & 6.00 & 3.83 & 4.82 & 4.77 & 4.82 & 4.99 & 3.59 & 4.36 & 3.33 \\
\hline$\delta^{53 / 52} \mathrm{Cr}_{\text {bulk }}$ & $\%$ & NA & 0.91 & NA & NA & 0.75 & NA & 0.82 & NA & 0.75 & NA & NA & 0.62 & NA & 0.50 & NA & NA & 0.47 & 0.44 \\
\hline$\delta^{53 / 52} \mathrm{Cr}_{\text {leach }}$ & $\%$ & NA & 0.95 & NA & NA & NA & NA & NA & NA & 0.89 & NA & NA & NA & NA & NA & NA & NA & NA & 0.46 \\
\hline $\mathrm{Cr} / \mathrm{Ti}$ & $\mu \mathrm{g} \cdot \mu \mathrm{g}^{-1}$ & 0.053 & 0.060 & 0.057 & 0.045 & 0.070 & 0.034 & 0.041 & 0.033 & 0.032 & 0.027 & 0.046 & 0.088 & 0.080 & 0.052 & 0.058 & 0.041 & 0.045 & 0.037 \\
\hline $\mathrm{Cr}_{\text {auth }}$ & $\mu g \cdot g^{-1}$ & 48.9 & 56.2 & 44.1 & 37.9 & 126.7 & 10.6 & 29.2 & 6.2 & 4.9 & 0.0 & 42.5 & 82.9 & 147.8 & 65.8 & 126.0 & 32.1 & 38.0 & 21.8 \\
\hline$f_{\text {auth }}$ & - & 0.41 & 0.47 & 0.45 & 0.31 & 0.55 & 0.08 & 0.24 & 0.05 & 0.03 & 0.00 & 0.32 & 0.65 & 0.61 & 0.40 & 0.46 & 0.23 & 0.31 & 0.16 \\
\hline TOC & $w t \%$ & 7.98 & 7.75 & 7.63 & 8.16 & 5.59 & 4.08 & 5.70 & 4.87 & 4.42 & 3.51 & 3.84 & 8.34 & 9.90 & 9.80 & 9.41 & 7.99 & 6.56 & 4.55 \\
\hline Mg & $\mu \mathrm{g} \cdot \mathrm{g}^{-1}$ & 11,408 & 11,328 & 10,564 & 11,332 & 14,219 & 13,067 & 13,891 & 13,788 & 21,888 & 11,853 & 11,319 & 14,757 & 12,342 & 11,921 & 20,827 & 12,461 & 13,618 & 12,470 \\
\hline Al & $\mu \mathrm{g} \cdot \mathrm{g}^{-1}$ & 47,407 & 44,369 & 38,930 & 58,201 & 73,263 & 77,842 & 69,526 & 77,055 & 132,728 & 73,182 & 54,159 & 31,472 & 67,070 & 68,757 & 108,278 & 76,328 & 57,193 & 75,915 \\
\hline Mn & $\mu \mathrm{g} \cdot \mathrm{g}^{-1}$ & 282 & 260 & 230 & 319 & 389 & 354 & 380 & 375 & 696 & 381 & 314 & 201 & 320 & 288 & 533 & 346 & 328 & 338 \\
\hline $\mathrm{Ba}$ & $\mu g \cdot g^{-1}$ & 376 & 387 & 325 & 430 & 367 & 389 & 351 & 492 & 685 & 408 & 847 & 160 & 309 & 316 & 499 & 365 & 255 & 339 \\
\hline $\mathrm{Ti}$ & $\mu \mathrm{g} \cdot \mathrm{g}^{-1}$ & 2,256 & 1,990 & 1,746 & 2,712 & 3,305 & 3,836 & 2,970 & 3,551 & 6,091 & 3,603 & 2,905 & 1,458 & 3,030 & 3,119 & 4,649 & 3,460 & 2,742 & 3,666 \\
\hline $\mathrm{Cr}$ & $\mu \mathrm{g} \cdot \mathrm{g}^{-1}$ & 119 & 118 & 99 & 123 & 230 & 131 & 122 & 117 & 195 & 98 & 133 & 129 & 243 & 163 & 271 & 140 & 124 & 136 \\
\hline $\mathrm{Fe}$ & $\mu g \cdot g^{-1}$ & 18,804 & 18,309 & 16,488 & 23,138 & 49,123 & 30,575 & 25,624 & 28,424 & 53,974 & 26,876 & 27,001 & 13,555 & 37,704 & 24,846 & 51,264 & 27,931 & 24,629 & 29,804 \\
\hline Co & $\mu g \cdot g^{-1}$ & 7.0 & 6.5 & 5.8 & 7.6 & 9.7 & 7.5 & 9.9 & 10.3 & 14.9 & 8.0 & 7.4 & 4.7 & 7.7 & 7.9 & 19.8 & 7.7 & 7.1 & 8.5 \\
\hline $\mathrm{Ni}$ & $\mu g \cdot g^{-1}$ & 78 & 78 & 73 & 72 & 83 & 26 & 69 & 65 & 70 & 41 & 110 & 116 & 126 & 113 & 362 & 62 & 84 & 70 \\
\hline $\mathrm{Cu}$ & $\mu \mathrm{g} \cdot \mathrm{g}^{-1}$ & 52 & 95 & 98 & 79 & 75 & 55 & 69 & 62 & 83 & 55 & 65 & 87 & 91 & 95 & 188 & 72 & 68 & 60 \\
\hline $\mathrm{Zn}$ & $\mu g \cdot g^{-1}$ & 95 & 87 & 101 & 115 & 157 & 126 & 128 & 184 & 218 & 131 & 150 & 86 & 146 & 148 & 317 & 149 & 129 & 158 \\
\hline Mo & $\mu g \cdot g^{-1}$ & 64 & 72 & 79 & 59 & 73 & 68 & 48 & 49 & 54 & 24 & 47 & 46 & 66 & 73 & 101 & 46 & 23 & 30 \\
\hline v & $\mu g \cdot g^{-1}$ & 242 & 219 & 222 & 218 & 258 & 171 & 192 & 166 & 224 & 122 & 122 & 190 & 298 & 294 & 465 & 200 & 161 & 161 \\
\hline U & $\mu g \cdot g^{-1}$ & 9.6 & 8.6 & 7.2 & 8.2 & 9.9 & 6.6 & 8.3 & 6.8 & 13.7 & 9.5 & 22.3 & 10.7 & 22.0 & 16.1 & 29.2 & 14.1 & 10.5 & 11.5 \\
\hline $\mathrm{Cd}$ & $\mu g \cdot g^{-1}$ & 85 & 77 & 62 & 30 & 51 & 1 & 43 & 52 & 35 & 23 & 28 & 45 & 35 & 33 & 189 & 10 & 45 & 14 \\
\hline $\mathrm{Pb}$ & $\mu g \cdot g^{-1}$ & 15.8 & 13.2 & 10.8 & 16.7 & 24.1 & 22.5 & 26.3 & 27.1 & 36.9 & 21.4 & 10.3 & 8.4 & 13.8 & 21.0 & 29.4 & 25.9 & 12.8 & 20.5 \\
\hline As & $\mu g \cdot g^{-1}$ & 19.8 & 16.6 & 14.5 & 16.1 & 31.2 & 17.2 & 16.4 & 17.3 & 35.7 & 18.9 & 29.5 & 10.1 & 28.5 & 17.9 & 47.1 & 20.6 & 23.4 & 17.4 \\
\hline $\mathbf{R b}$ & $\mu \mathrm{g} \cdot \mathrm{g}^{-1}$ & 64 & 55 & 52 & 76 & 96 & 111 & 101 & 109 & 151 & 91 & 68 & 42 & 88 & 89 & 131 & 106 & 78 & 92 \\
\hline $\mathrm{Sr}$ & $\mu \mathrm{g} \cdot \mathrm{g}^{-1}$ & 509 & 396 & 315 & 249 & 276 & 202 & 291 & 217 & 393 & 274 & 400 & 301 & 249 & 194 & 342 & 197 & 241 & 217 \\
\hline $\mathrm{Zr}$ & $\mu \mathrm{g} \cdot \mathrm{g}^{-1}$ & 35 & 33 & 25 & 72 & 61 & 76 & 55 & 83 & 104 & 76 & 42 & 31 & 52 & 57 & 92 & 66 & 53 & 76 \\
\hline w & $\mu \mathrm{g} \cdot \mathrm{g}^{-1}$ & 1.0 & 0.9 & 1.0 & 1.1 & 1.3 & 1.4 & 1.1 & 1.3 & 3.0 & 1.3 & 1.1 & 0.7 & 1.5 & 1.3 & 2.3 & 1.8 & 1.1 & 1.4 \\
\hline
\end{tabular}




Table 1b.
\begin{tabular}{|cc|}
\hline Sample name & Cr/Ti \\
\hline & $\mu \mathrm{g} \cdot \mu \mathrm{g}^{-1}$ \\
$1 \mathrm{H} 2-110$ & 0.382 \\
$1 \mathrm{H} 2-130$ & 0.330 \\
$1 \mathrm{H} 3-002$ & 0.384 \\
$1 \mathrm{H} 3-062$ & 0.315 \\
$1 \mathrm{H} 3-102$ & 0.329 \\
$1 \mathrm{H} 3-122$ & 0.359 \\
$1 \mathrm{H} 3-142$ & 0.292 \\
$1 \mathrm{H} 4-050$ & 0.313 \\
$1 \mathrm{H} 4-090$ & 0.344 \\
\hline
\end{tabular}


Table 2: Cariaco Basin bulk sediment sample data.

\begin{tabular}{|c|c|c|c|c|c|c|c|c|}
\hline Sample name & Units & PL07-22BX & PL07-89BX & PL07-82BX & PL07-105BX & PL07-67BX & PL07-69BX & PL07-111BX \\
\hline Sample number & - & 1 & 2 & 3 & 4 & 5 & 6 & 7 \\
\hline Water depth & $\mathrm{m}$ & 656 & 1342 & 818 & 1296 & 400 & 545 & 411 \\
\hline$\delta^{53 / 52} \mathrm{Cr}_{\text {bulk }}$ & $\%$ & 0.31 & 0.25 & 0.28 & 0.17 & 0.29 & 0.29 & 0.17 \\
\hline$\delta^{53 / 52} \mathrm{Cr}_{\text {leach }}{ }^{*}$ & $\%$ & 0.42 & 0.35 & 0.43 & 0.28 & 0.37 & 0.41 & 0.39 \\
\hline $\mathrm{Cr} / \mathrm{Ti}$ & $\mu g \cdot \mu g^{-1}$ & 0.036 & 0.033 & 0.035 & 0.033 & 0.034 & 0.034 & 0.034 \\
\hline $\mathrm{Ti}$ & $\mu g \cdot g^{-1}$ & 2418 & 3412 & 2966 & 3307 & 3282 & 3648 & 3975 \\
\hline $\mathrm{Cr}$ & $\mu g \cdot g^{-1}$ & 88 & 113 & 105 & 109 & 112 & 125 & 135 \\
\hline $\mathrm{Fe}$ & $\mu g \cdot g^{-1}$ & 26762 & 42679 & 33537 & 42490 & 35291 & 39210 & 43608 \\
\hline Co & $\mu g \cdot g^{-1}$ & 9 & 13 & 11 & 14 & 12 & 12 & 14 \\
\hline $\mathrm{Ni}$ & $\mu g \cdot g^{-1}$ & 59 & 79 & 72 & 72 & 81 & 78 & 79 \\
\hline $\mathrm{Cu}$ & $\mu g \cdot g^{-1}$ & 29 & 36 & 33 & 37 & 35 & 35 & 41 \\
\hline $\mathrm{Zn}$ & $\mu g \cdot g^{-1}$ & 96 & 155 & 129 & 136 & 136 & 136 & 157 \\
\hline Mo & $\mu g \cdot g^{-1}$ & 16.0 & 33.7 & 50.4 & 28.5 & 57.4 & 89.3 & 22.3 \\
\hline V & $\mu g \cdot g^{-1}$ & 192 & 260 & 226 & 266 & 282 & 265 & 293 \\
\hline $\mathbf{U}$ & $\mu g \cdot g^{-1}$ & 4.4 & 6.1 & 7.7 & 6.0 & 7.8 & 10.4 & 5.4 \\
\hline $\mathrm{Nb}$ & $\mu g \cdot g^{-1}$ & 7.9 & 10.7 & 9.4 & 10.5 & 10.5 & 12.3 & 12.5 \\
\hline Cd & $\mu g \cdot g^{-1}$ & 1.0 & 3.2 & 2.7 & 3.3 & 3.4 & 3.1 & 2.3 \\
\hline La & $\mu g \cdot g^{-1}$ & 24.2 & 32.2 & 29.0 & 30.6 & 33.0 & 35.9 & 36.1 \\
\hline $\mathrm{Ce}$ & $\mu g \cdot g^{-1}$ & 47.6 & 64.5 & 56.9 & 60.5 & 63.9 & 70.2 & 70.3 \\
\hline TI & $\mu g \cdot g^{-1}$ & 0.4 & 0.5 & 0.5 & 0.5 & 0.5 & 0.6 & 0.7 \\
\hline $\mathrm{Pb}$ & $\mu g \cdot g^{-1}$ & 34.0 & 40.6 & 37.2 & 36.0 & 41.9 & 40.6 & 40.1 \\
\hline Th & $\mu \mathrm{g} \cdot \mathrm{g}^{-1}$ & 8.4 & 8.0 & 9.6 & 11.1 & 10.8 & 12.1 & 13.5 \\
\hline
\end{tabular}

${ }^{*} \mathrm{Cr}$ isotope composition measured in the leach fraction. 
Table 3: Oxic global marine core-top sediment sample data.

\begin{tabular}{|c|c|c|c|c|c|c|c|c|c|}
\hline Sample name & Units & All31-2PG & All93-24PG & All93-36PG & CHN115-48PG & CHN57-2PG & CHN75-2-PG & CHN75-9PG & EN066-17GGC \\
\hline Latitude & deg & 10.5833 & -6.6950 & -13.0067 & -26.8533 & 20.0933 & 19.4917 & 14.2333 & 5.3667 \\
\hline Longitude & deg & -44.8500 & 130.1117 & 112.5750 & -27.3900 & -64.5750 & -60.7750 & -55.7867 & -21.0883 \\
\hline Water depth & $\mathrm{m}$ & 5106 & 5467 & 5222 & 5933 & 5808 & 5262 & 5141 & 3014 \\
\hline $\begin{array}{l}\text { Depth in the } \\
\text { sediment }\end{array}$ & cmbsf & $0-2$ & $0-1.5$ & $0-1$ & $1-2$ & $0-2$ & $23-24$ & $10-11$ & $12-13$ \\
\hline$\delta^{53 / 52} \mathrm{Cr}_{\text {bulk }}$ & $\%$ & -0.06 & 0.06 & -0.06 & -0.06 & -0.01 & -0.05 & -0.07 & -0.08 \\
\hline$\delta^{53 / 52} \mathrm{Cr}_{\text {leach }}{ }^{*}$ & $\%$ & $N A^{\star *}$ & NA & NA & NA & 0.02 & NA & NA & NA \\
\hline $\mathrm{Cr} / \mathrm{Ti}$ & $\mu \mathrm{g} \cdot \mu \mathrm{g}^{-1}$ & 0.017 & 0.018 & 0.012 & 0.012 & 0.025 & 0.019 & 0.017 & 0.016 \\
\hline $\mathrm{Ti}$ & $\mu g \cdot g^{-1}$ & 3053 & 4242 & 6285 & 5062 & 3643 & 3887 & 4342 & 1137 \\
\hline $\mathrm{Cr}$ & $\mu g \cdot g^{-1}$ & 51 & 77 & 74 & 59 & 89 & 72 & 74 & 18 \\
\hline $\mathrm{Ba}$ & $\mu \mathrm{g} \cdot \mathrm{g}^{-1}$ & 276 & 563 & 1068 & 442 & 263 & 311 & 342 & 431 \\
\hline Mn & $\mu g \cdot g^{-1}$ & 1305 & 282 & 7228 & 8951 & 2093 & 2999 & 1471 & 639 \\
\hline $\mathrm{Fe}$ & $\mu g \cdot g^{-1}$ & 33124 & 48534 & 58117 & 57381 & 45132 & 45434 & 45271 & 10247 \\
\hline Co & $\mu g \cdot g^{-1}$ & 15.8 & 18.1 & 63.2 & 94.5 & 32.5 & 37.7 & 20.7 & 6.9 \\
\hline $\mathrm{Ni}$ & $\mu g \cdot g^{-1}$ & 43.8 & 100.3 & 410.6 & 192.9 & 76.8 & 80.9 & 52.0 & 33.6 \\
\hline $\mathrm{Cu}$ & $\mu g \cdot g^{-1}$ & 75.9 & 93.6 & 432.3 & 162.9 & 86.8 & 85.5 & 78.5 & 33.9 \\
\hline$Z n$ & $\mu g \cdot g^{-1}$ & 73.8 & 130.6 & 187.2 & 134.2 & 75.5 & 95.3 & 104.8 & 5.0 \\
\hline Mo & $\mu g \cdot g^{-1}$ & 2.0 & 0.5 & 23.3 & 19.2 & 3.8 & 3.7 & 2.1 & $<\mathrm{DL}$ \\
\hline v & $\mu g \cdot g^{-1}$ & 89.8 & 194.2 & 133.1 & 138.7 & 120.6 & 119.8 & 128.2 & 28.3 \\
\hline $\mathrm{U}$ & $\mu g \cdot g^{-1}$ & 1.07 & 1.95 & 1.60 & 1.96 & 1.43 & 1.50 & 1.69 & 0.45 \\
\hline $\mathrm{Nb}$ & $\mu \mathrm{g} \cdot \mathrm{g}^{-1}$ & 10.4 & 10.1 & 15.1 & 14.0 & 10.4 & 12.3 & 15.0 & 4.7 \\
\hline Cd & $\mu g \cdot g^{-1}$ & $<\mathrm{DL}^{\star \star \star}$ & $<\mathrm{DL}$ & 0.6 & 0.9 & $<\mathrm{DL}$ & $<\mathrm{DL}$ & $<\mathrm{DL}$ & $<\mathrm{DL}$ \\
\hline La & $\mu g \cdot g^{-1}$ & 27.6 & 25.4 & 54.6 & 40.5 & 30.6 & 33.8 & 35.0 & 13.4 \\
\hline $\mathrm{Ce}$ & $\mu g \cdot g^{-1}$ & 54.4 & 56.8 & 77.4 & 115.5 & 70.9 & 79.4 & 75.9 & 21.4 \\
\hline TI & $\mu g \cdot g^{-1}$ & 0.27 & 0.29 & 0.99 & 0.99 & 0.49 & 0.66 & 0.50 & 0.08 \\
\hline $\mathrm{Pb}$ & $\mu g \cdot g^{-1}$ & 15.39 & 20.25 & 35.67 & 35.82 & 17.97 & 23.12 & 21.97 & 4.30 \\
\hline Th & $\mu \mathrm{g} \cdot \mathrm{g}^{-1}$ & 7.19 & 8.77 & 14.88 & 14.66 & 8.80 & 10.31 & 9.55 & 2.54 \\
\hline
\end{tabular}

${ }^{*} \mathrm{Cr}$ isotope composition measured in the leach fraction

** NA: not analyzed.

${ }^{* \star *}<\mathrm{DL}$ : below detection limit. 


\begin{tabular}{|c|c|c|c|c|c|c|c|c|c|c|}
\hline Sample name & Units & EN066-20GGC & EN066-30GGC & EW9302-30GGCE & EW9302-GGC0ミ & KNR102-1PG & KNR102-2PG & KNR102-4PG & KNR110-19JGC & KNR110-19JGC \\
\hline Latitude & deg & 5.0833 & 2.3583 & 62.7505 & 49.9020 & 28.9133 & 28.9567 & 30.1717 & 6.2883 & 6.2883 \\
\hline Longitude & $\operatorname{deg}$ & -20.9867 & -19.7150 & -20.6775 & -44.4642 & -70.9450 & -71.1033 & -69.7733 & -44.0750 & -44.0750 \\
\hline Water depth & $\mathrm{m}$ & 2756 & 5228 & 1188 & 4082 & 5370 & 5365 & 5300 & 4576 & 4576 \\
\hline $\begin{array}{l}\text { Depth in the } \\
\text { sediment }\end{array}$ & cmbsf & $2-4$ & $2-4$ & $0-3$ & $2-4$ & $0-2$ & $0-2$ & $3-4$ & $2-3$ & $2-3$ \\
\hline$\delta^{53 / 52} \mathrm{Cr}_{\text {bulk }}$ & $\%$ & -0.08 & -0.13 & -0.14 & -0.13 & -0.08 & -0.06 & -0.02 & -0.03 & -0.03 \\
\hline$\delta^{53 / 52} \mathrm{Cr}_{\text {leach }}$ & $\%$ & NA & NA & NA & NA & NA & NA & NA & 0.01 & 0.01 \\
\hline $\mathrm{Cr} / \mathrm{Ti}$ & $\mu \mathrm{g} \cdot \mu \mathrm{g}^{-1}$ & 0.015 & 0.018 & 0.002 & 0.016 & 0.011 & 0.014 & 0.023 & 0.017 & 0.017 \\
\hline $\mathrm{Ti}$ & $\mu g \cdot g^{-1}$ & 1105 & 1602 & 17107 & 2915 & 4235 & 5112 & 4322 & 3363 & 3363 \\
\hline $\mathrm{Cr}$ & $\mu g \cdot g^{-1}$ & 17 & 28 & 37 & 47 & 47 & 71 & 100 & 58 & 58 \\
\hline $\mathrm{Ba}$ & $\mu g \cdot g^{-1}$ & 260 & 147 & 237 & 377 & 333 & 417 & 547 & 317 & 317 \\
\hline Mn & $\mu g \cdot g^{-1}$ & 261 & 2483 & 1725 & 801 & 955 & 1069 & 14242 & 1250 & 1250 \\
\hline $\mathrm{Fe}$ & $\mu g \cdot g^{-1}$ & 9551 & 16236 & 85278 & 24185 & 24641 & 36652 & 55105 & 36311 & 36311 \\
\hline Co & $\mu g \cdot g^{-1}$ & 5.4 & 11.4 & 36.5 & 11.4 & 12.0 & 17.2 & 109.2 & 16.7 & 16.7 \\
\hline $\mathbf{N i}$ & $\mu \mathrm{g} \cdot \mathrm{g}^{-1}$ & 16.0 & 60.4 & 28.1 & 29.6 & 28.3 & 40.9 & 113.4 & 44.5 & 44.5 \\
\hline $\mathrm{Cu}$ & $\mu g \cdot g^{-1}$ & 21.2 & 87.5 & 55.3 & 20.3 & 20.0 & 27.5 & 141.4 & 68.1 & 68.1 \\
\hline $\mathrm{Zn}$ & $\mu \mathrm{g} \cdot \mathrm{g}^{-1}$ & 22.1 & 44.9 & 120.1 & 40.1 & 44.4 & 74.1 & 245.1 & 90.8 & 90.8 \\
\hline Mo & $\mu g \cdot g^{-1}$ & 0.5 & 2.2 & 1.3 & $<\mathrm{DL}$ & $<\mathrm{DL}$ & 0.8 & 30.9 & 1.6 & 1.6 \\
\hline V & $\mu \mathrm{g} \cdot \mathrm{g}^{-1}$ & 28.2 & 45.9 & 263.7 & 60.2 & 64.7 & 102.3 & 195.2 & 107.3 & 107.3 \\
\hline $\mathbf{U}$ & $\mu \mathrm{g} \cdot \mathrm{g}^{-1}$ & 0.48 & 0.64 & 0.73 & 0.82 & 1.57 & 1.76 & 1.93 & 1.25 & 1.25 \\
\hline $\mathrm{Nb}$ & $\mu g \cdot g^{-1}$ & 4.7 & 6.9 & 27.3 & 7.8 & 12.6 & 15.8 & 14.7 & 11.3 & 11.3 \\
\hline Cd & $\mu g \cdot g^{-1}$ & $<\mathrm{DL}$ & $<\mathrm{DL}$ & $<\mathrm{DL}$ & $<\mathrm{DL}$ & $<\mathrm{DL}$ & $<\mathrm{DL}$ & 0.8 & $<\mathrm{DL}$ & $<\mathrm{DL}$ \\
\hline La & $\mu \mathrm{g} \cdot \mathrm{g}^{-1}$ & 11.5 & 16.5 & 21.6 & 19.1 & 26.5 & 23.5 & 40.7 & 28.4 & 28.4 \\
\hline $\mathrm{Ce}$ & $\mu g \cdot g^{-1}$ & 18.7 & 33.0 & 48.4 & 38.7 & 58.0 & 54.1 & 93.1 & 57.0 & 57.0 \\
\hline TI & $\mu g \cdot g^{-1}$ & 0.09 & 0.26 & 0.03 & 0.14 & 0.21 & 0.38 & 1.98 & 0.38 & 0.38 \\
\hline $\mathrm{Pb}$ & $\mu g \cdot g^{-1}$ & 6.10 & 7.88 & 5.52 & 9.64 & 11.34 & 16.81 & 24.75 & 15.33 & 15.33 \\
\hline Th & $\mu \mathrm{g} \cdot \mathrm{g}^{-1}$ & 0.78 & 3.70 & 2.15 & 4.20 & 6.72 & 6.01 & 11.05 & 5.70 & 5.70 \\
\hline
\end{tabular}




\begin{tabular}{|c|c|c|c|c|c|c|c|c|c|}
\hline Sample name & Units & KNR-110-79GGC & KNR140-GGC21 & KNR140-2-48GGC & KNR159-51GGC & KNR159-5-54GGC & KNR176-2-8GGC & RNDBT6-12GGC & RNDBT6-21GGC \\
\hline Latitude & deg & 4.3250 & 28.2458 & 32.7462 & -25.8823 & -29.5362 & 6.8205 & 51.0608 & 51.4150 \\
\hline Longitude & deg & -43.5033 & -74.4103 & -76.1258 & -43.3062 & -43.3378 & -77.9364 & 168.0832 & 167.4067 \\
\hline Water depth & $\mathrm{m}$ & 2821 & 4705 & 2100 & 2150 & 4003 & 2896 & 3416 & 2727 \\
\hline $\begin{array}{l}\text { Depth in the } \\
\text { sediment }\end{array}$ & cmbsf & $4.5-6$ & $0-2$ & $0-2$ & $1-2$ & $5-7$ & $0-2$ & $4-5$ & $1-2$ \\
\hline$\delta^{53 / 52} \mathrm{Cr}_{\text {bulk }}$ & $\%$ & -0.07 & 0.00 & 0.23 & 0.02 & -0.01 & -0.10 & -0.11 & -0.10 \\
\hline$\delta^{53 / 52} \mathrm{Cr}_{\text {leach }}$ & $\%$ & NA & 0.10 & NA & NA & NA & -0.21 & NA & NA \\
\hline $\mathrm{Cr} / \mathrm{Ti}$ & $\mu \mathrm{g} \cdot \mu \mathrm{g}^{-1}$ & 0.019 & 0.022 & 0.023 & 0.015 & 0.013 & 0.039 & 0.012 & 0.013 \\
\hline $\mathrm{Ti}$ & $\mu g \cdot g^{-1}$ & 1392 & 3365 & 2347 & 2586 & 3724 & 4524 & 2529 & 3716 \\
\hline $\mathrm{Cr}$ & $\mu \mathrm{g} \cdot \mathrm{g}^{-1}$ & 26 & 75 & 55 & 40 & 48 & 177 & 30 & 50 \\
\hline $\mathrm{Ba}$ & $\mu \mathrm{g} \cdot \mathrm{g}^{-1}$ & 202 & 331 & 226 & 245 & 606 & 233 & 1947 & 1132 \\
\hline Mn & $\mu \mathrm{g} \cdot \mathrm{g}^{-1}$ & 352 & 1756 & 479 & 663 & 1653 & 391 & 1410 & 622 \\
\hline $\mathrm{Fe}$ & $\mu g \cdot g^{-1}$ & 14436 & 37803 & 21144 & 23441 & 37046 & 57713 & 28411 & 42592 \\
\hline Co & $\mu g \cdot g^{-1}$ & 7.2 & 22.5 & 7.5 & 11.9 & 19.6 & 23.5 & 15.0 & 17.2 \\
\hline $\mathrm{Ni}$ & $\mu g \cdot g^{-1}$ & 17.1 & 50.5 & 27.7 & 23.7 & 45.3 & 83.6 & 33.2 & 33.6 \\
\hline $\mathrm{Cu}$ & $\mu \mathrm{g} \cdot \mathrm{g}^{-1}$ & 24.6 & 55.5 & 20.5 & 29.2 & 74.1 & 76.9 & 50.0 & 48.5 \\
\hline $\mathbf{Z n}$ & $\mu g \cdot g^{-1}$ & 35.1 & 93.9 & 56.2 & 46.8 & 85.7 & 54.3 & 58.5 & 115.0 \\
\hline Mo & $\mu \mathrm{g} \cdot \mathrm{g}^{-1}$ & $<\mathrm{DL}$ & 1.6 & $<\mathrm{DL}$ & 0.9 & 1.7 & $<\mathrm{DL}$ & $<\mathrm{DL}$ & 1.2 \\
\hline V & $\mu g \cdot g^{-1}$ & 46.5 & 100.1 & 61.9 & 54.8 & 88.8 & 146.9 & 85.6 & 109.3 \\
\hline U & $\mu g \cdot g^{-1}$ & 0.79 & 1.21 & 2.79 & 1.14 & 1.29 & 1.10 & 0.63 & 1.38 \\
\hline $\mathrm{Nb}$ & $\mu \mathrm{g} \cdot \mathrm{g}^{-1}$ & 4.8 & 10.0 & 6.6 & 8.2 & 9.8 & 3.8 & 2.5 & 7.2 \\
\hline Cd & $\mu \mathrm{g} \cdot \mathrm{g}^{-1}$ & $<\mathrm{DL}$ & $<D L$ & $<\mathrm{DL}$ & $<D L$ & $<\mathrm{DL}$ & $<\mathrm{DL}$ & $<\mathrm{DL}$ & $<\mathrm{DL}$ \\
\hline La & $\mu g \cdot g^{-1}$ & 14.4 & 29.1 & 19.9 & 19.6 & 24.1 & 5.9 & 8.2 & 18.5 \\
\hline $\mathrm{Ce}$ & $\mu g \cdot g^{-1}$ & 24.9 & 62.7 & 36.1 & 36.5 & 48.2 & 12.4 & 17.0 & 40.7 \\
\hline TI & $\mu g \cdot g^{-1}$ & 0.15 & 0.34 & 0.17 & 0.20 & 0.31 & - & 0.09 & 0.20 \\
\hline $\mathrm{Pb}$ & $\mu \mathrm{g} \cdot \mathrm{g}^{-1}$ & 6.81 & 14.69 & 7.07 & 9.94 & 14.06 & 5.55 & 8.67 & 12.73 \\
\hline Th & $\mu \mathrm{g} \cdot \mathrm{g}^{-1}$ & 3.45 & 7.17 & 4.33 & 5.36 & 6.93 & 1.01 & 1.71 & 4.62 \\
\hline
\end{tabular}




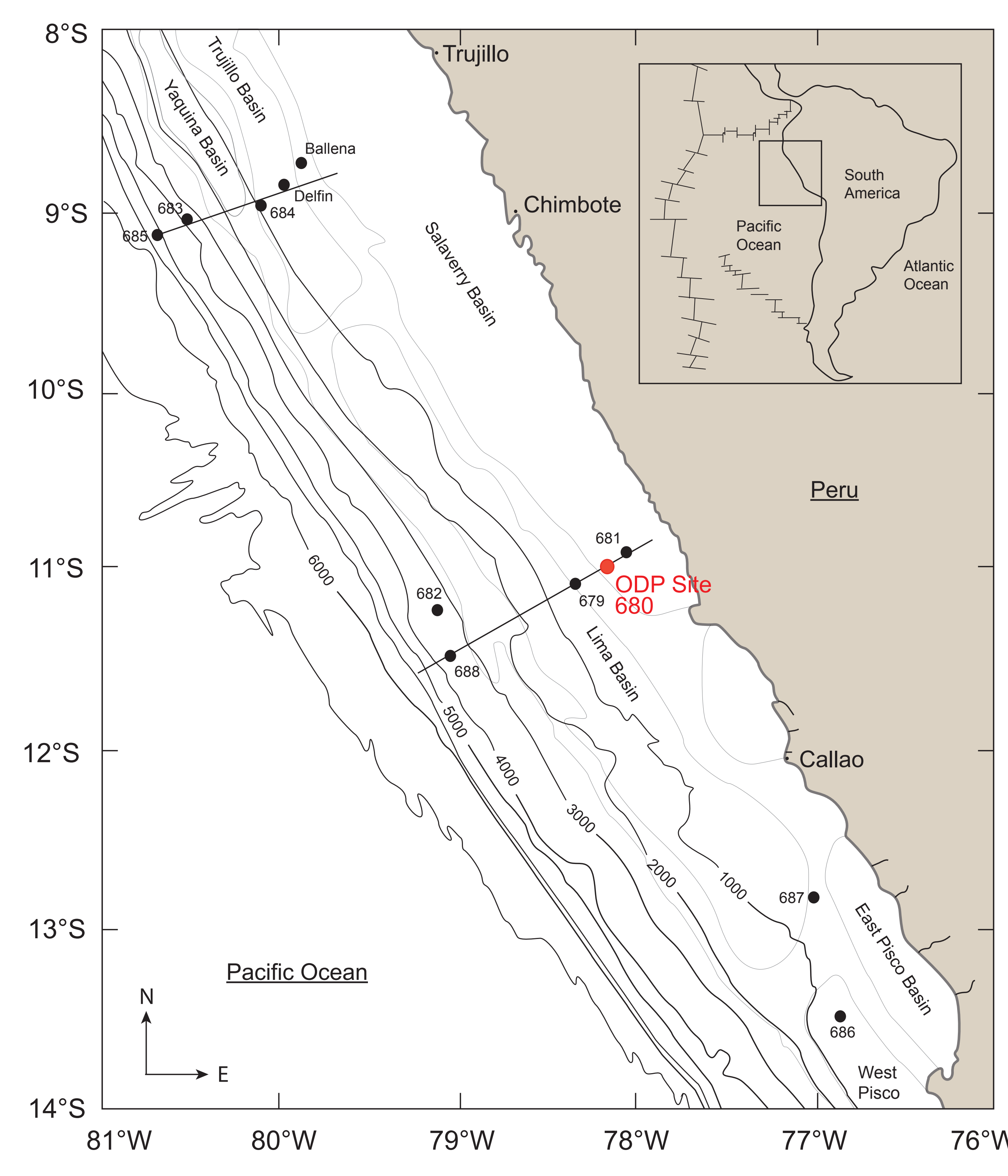

(a)

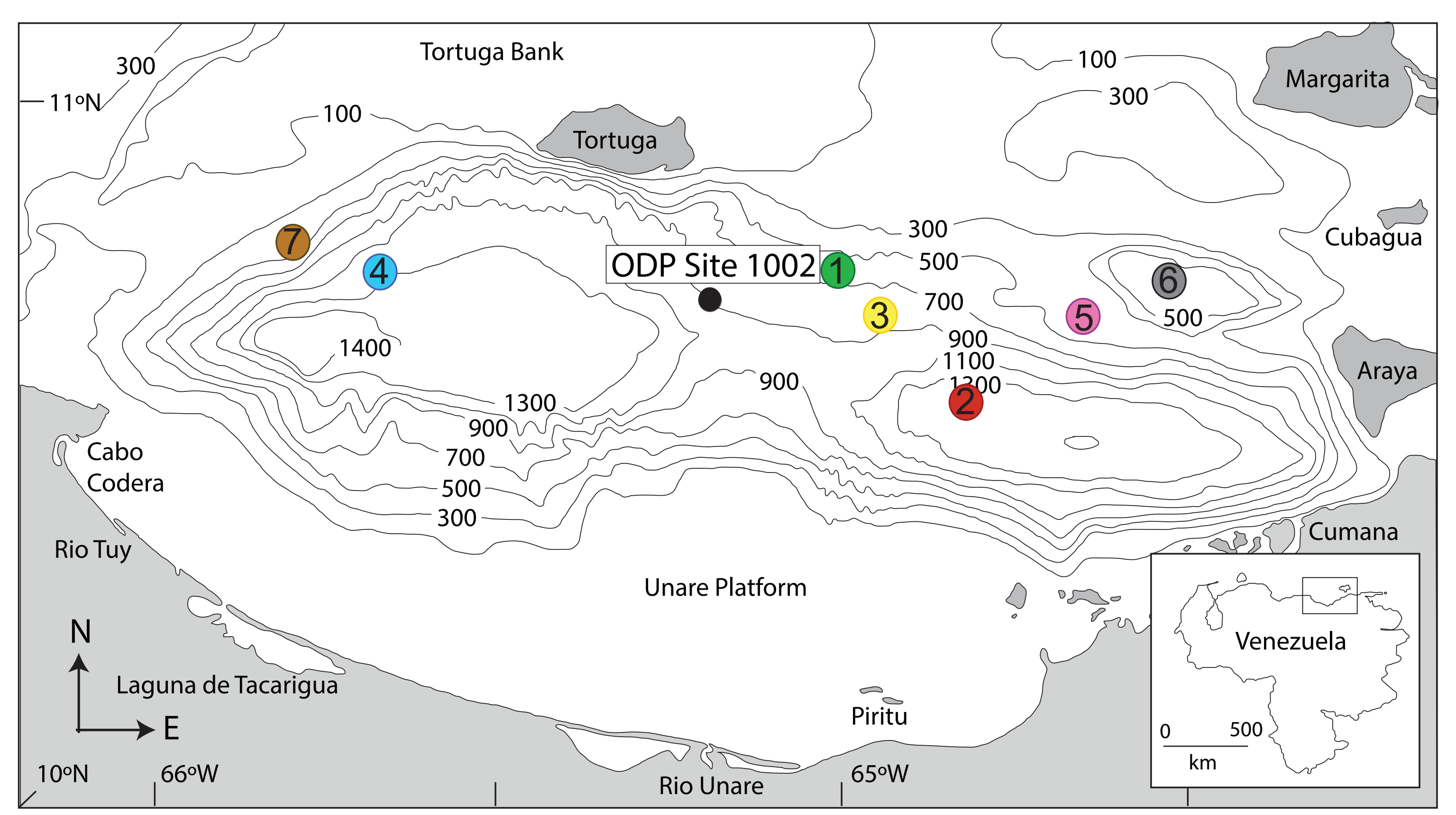

(b)

Figure 1

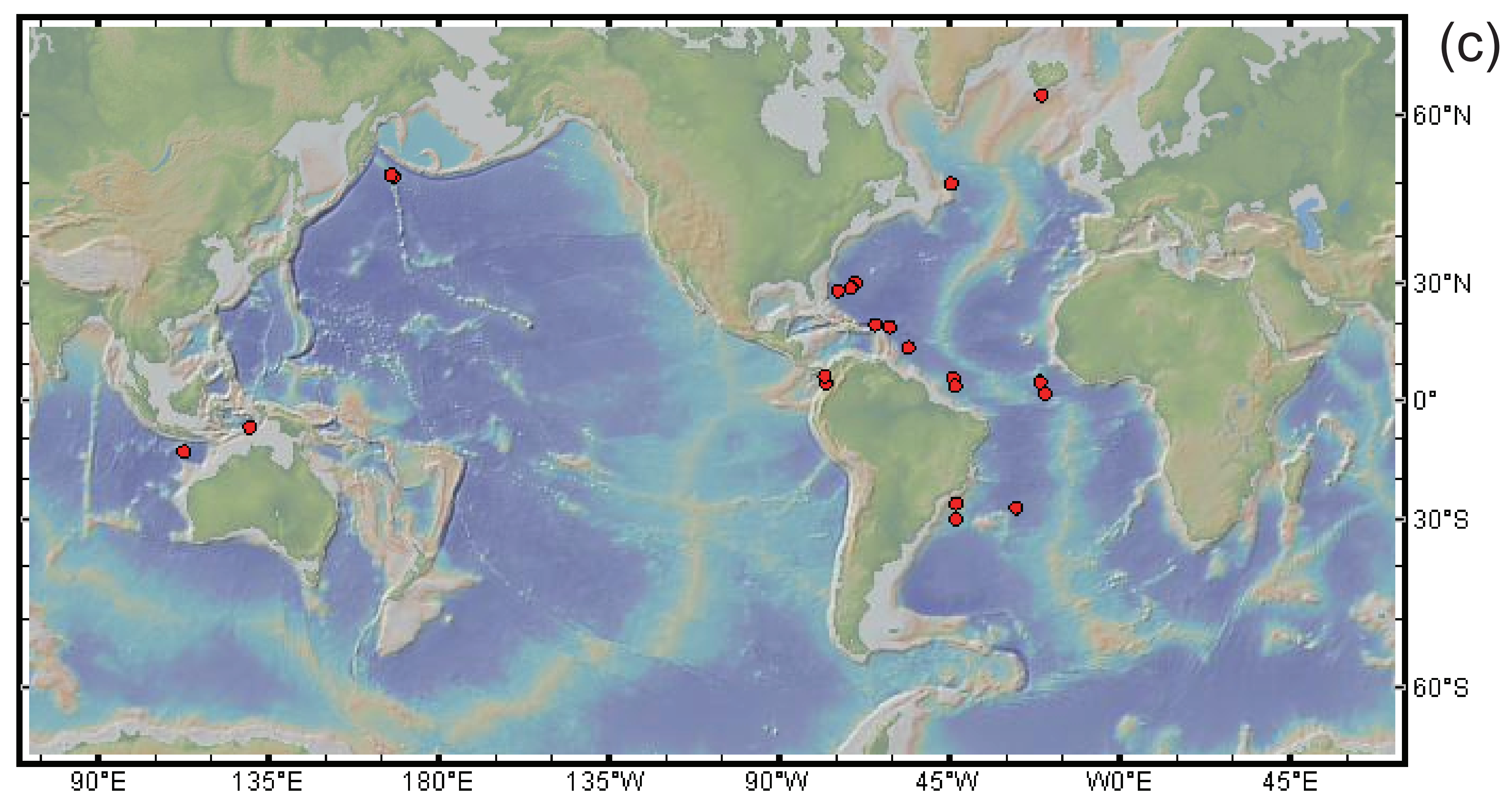




\section{Peru Margin}
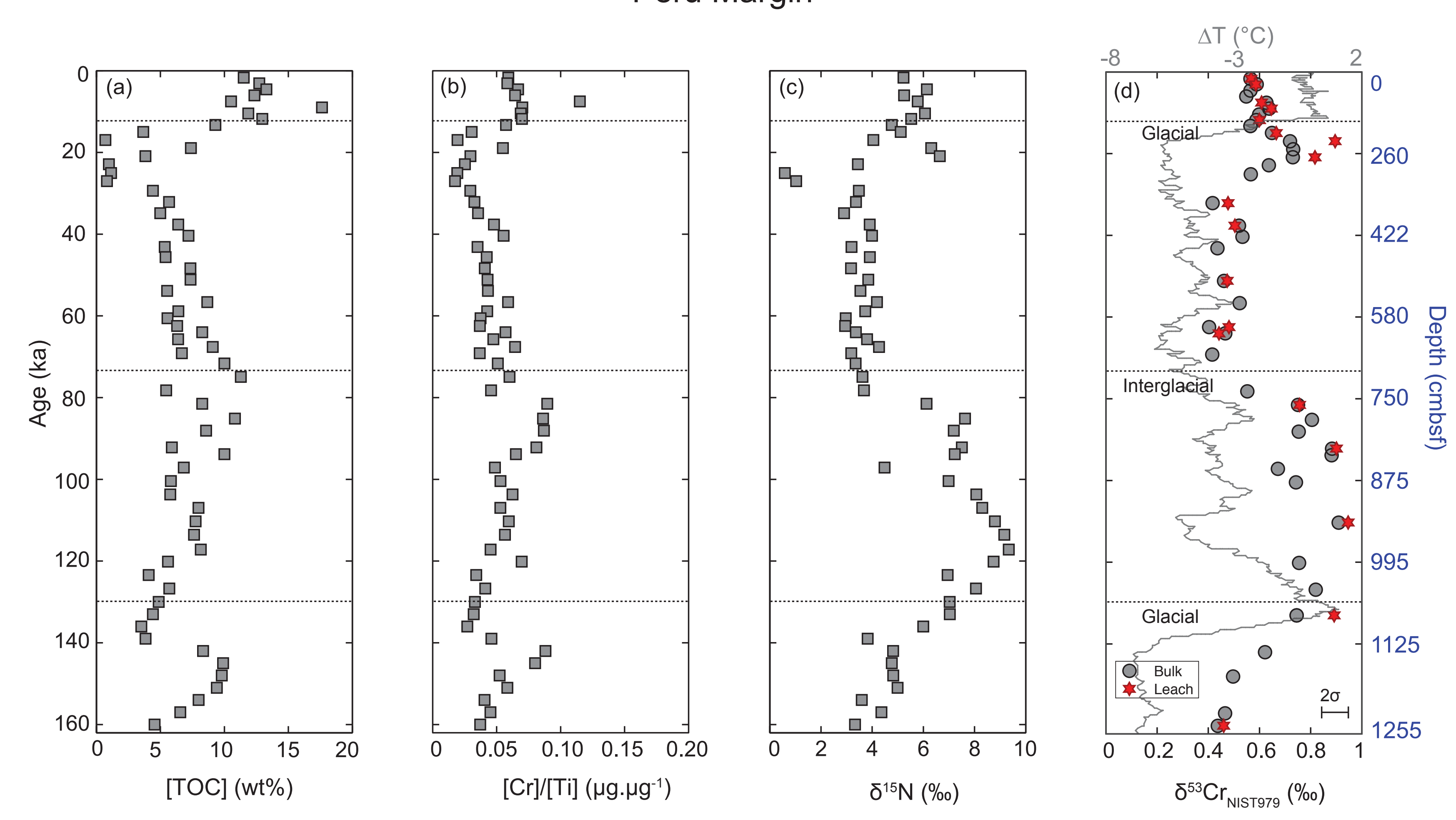

Figure 2 


\section{Peru Margin}
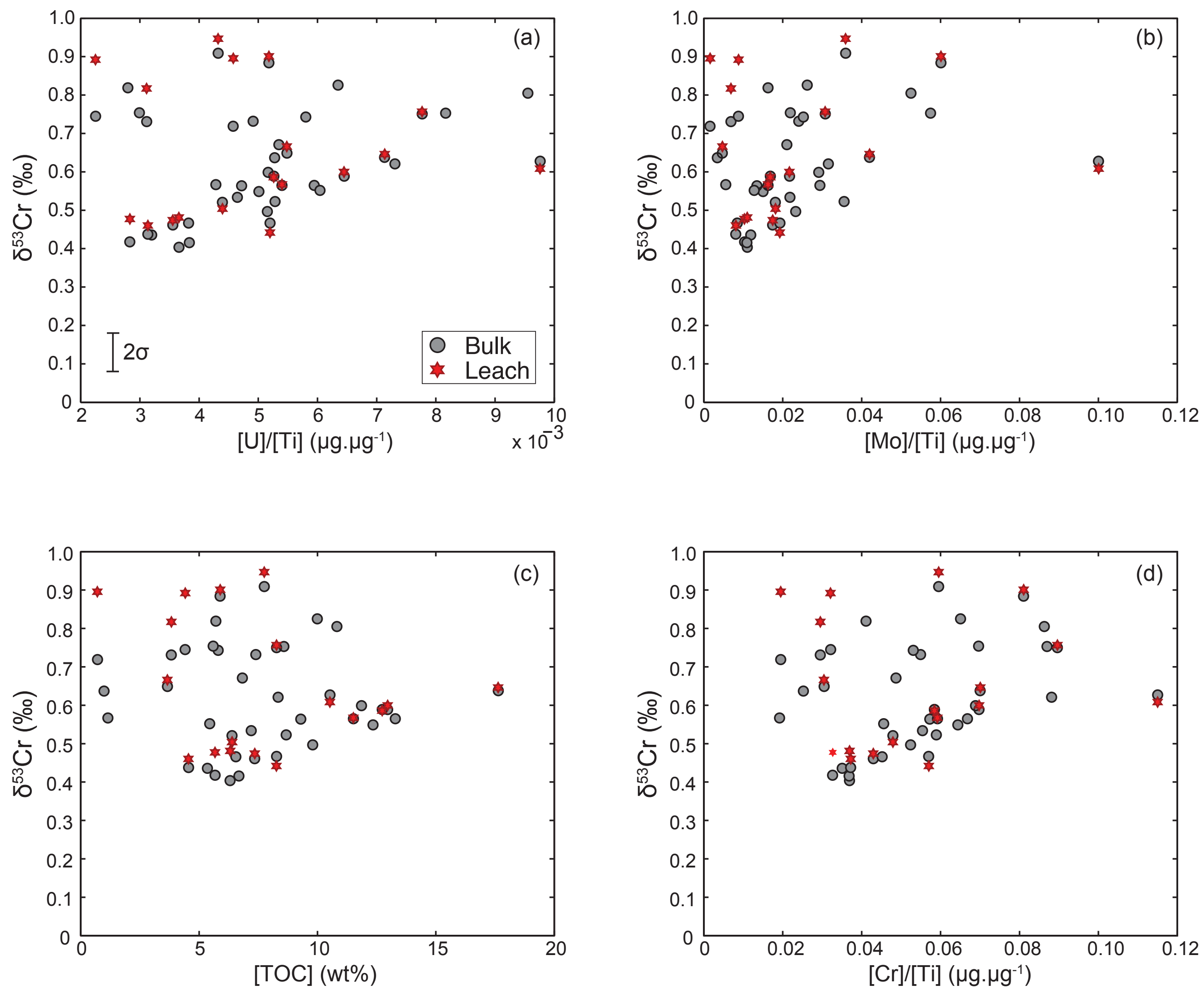

Figure 3 


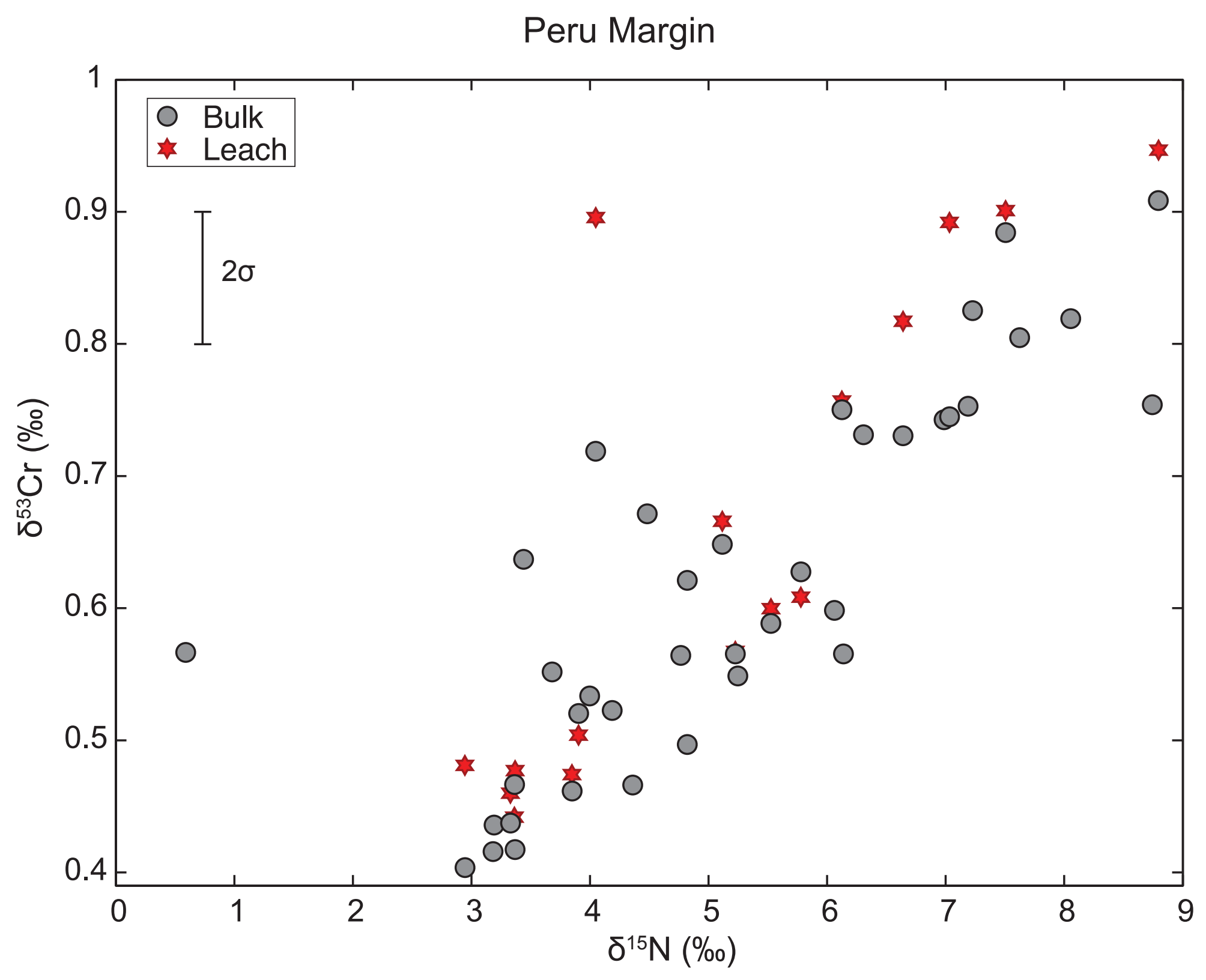

Figure 4 


\section{Cariaco Basin}

$\delta^{53} \mathrm{Cr}_{\text {NIST979 }}(\%)$

$\begin{array}{lllllllllll}0 & 0.1 & 0.2 & 0.3 & 0.4 & 0.5 & 0.6 & 0.7 & 0.8 & 0.9 & 1.0\end{array}$

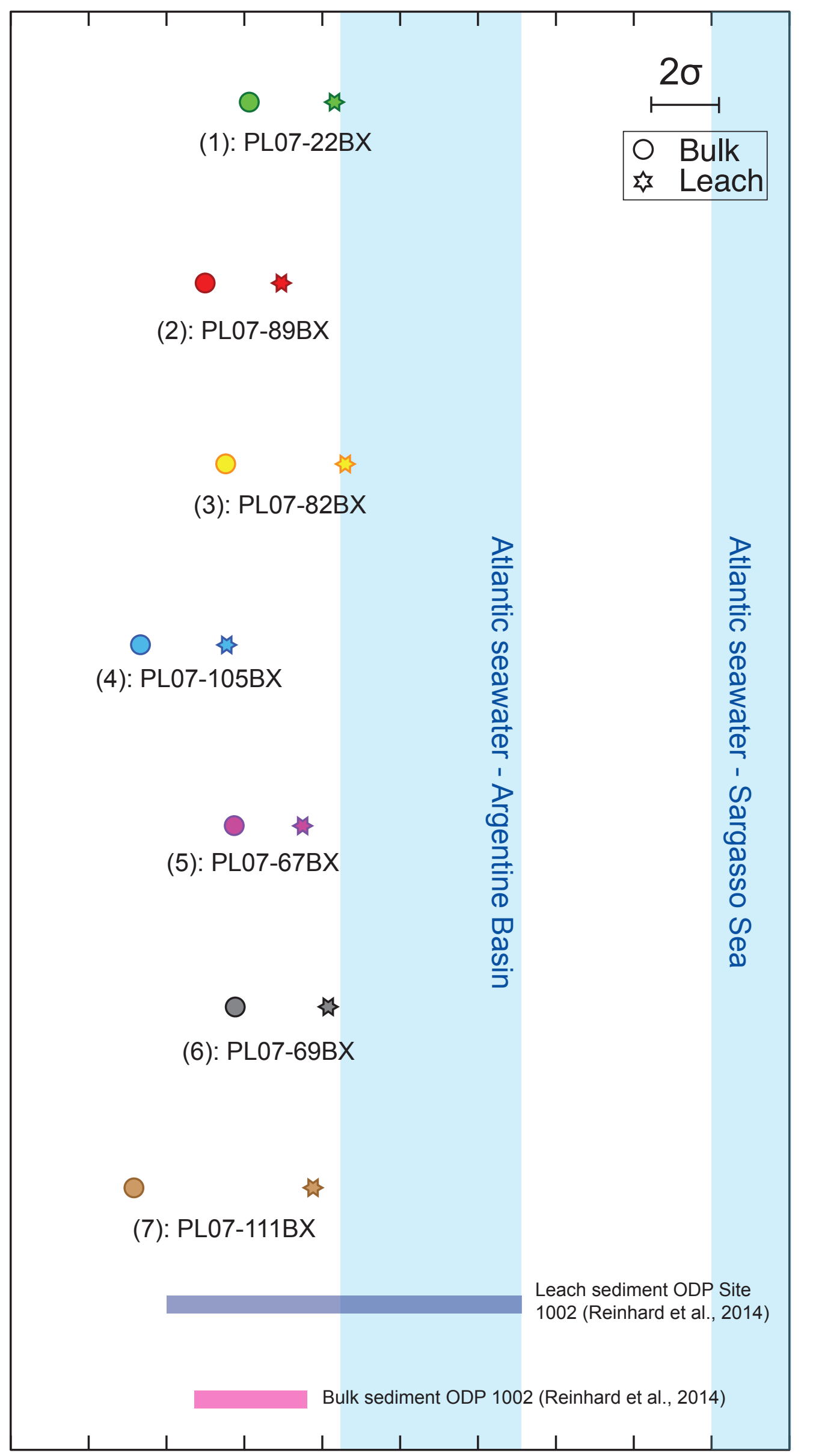

Figure 5 
Oxic marine sediments

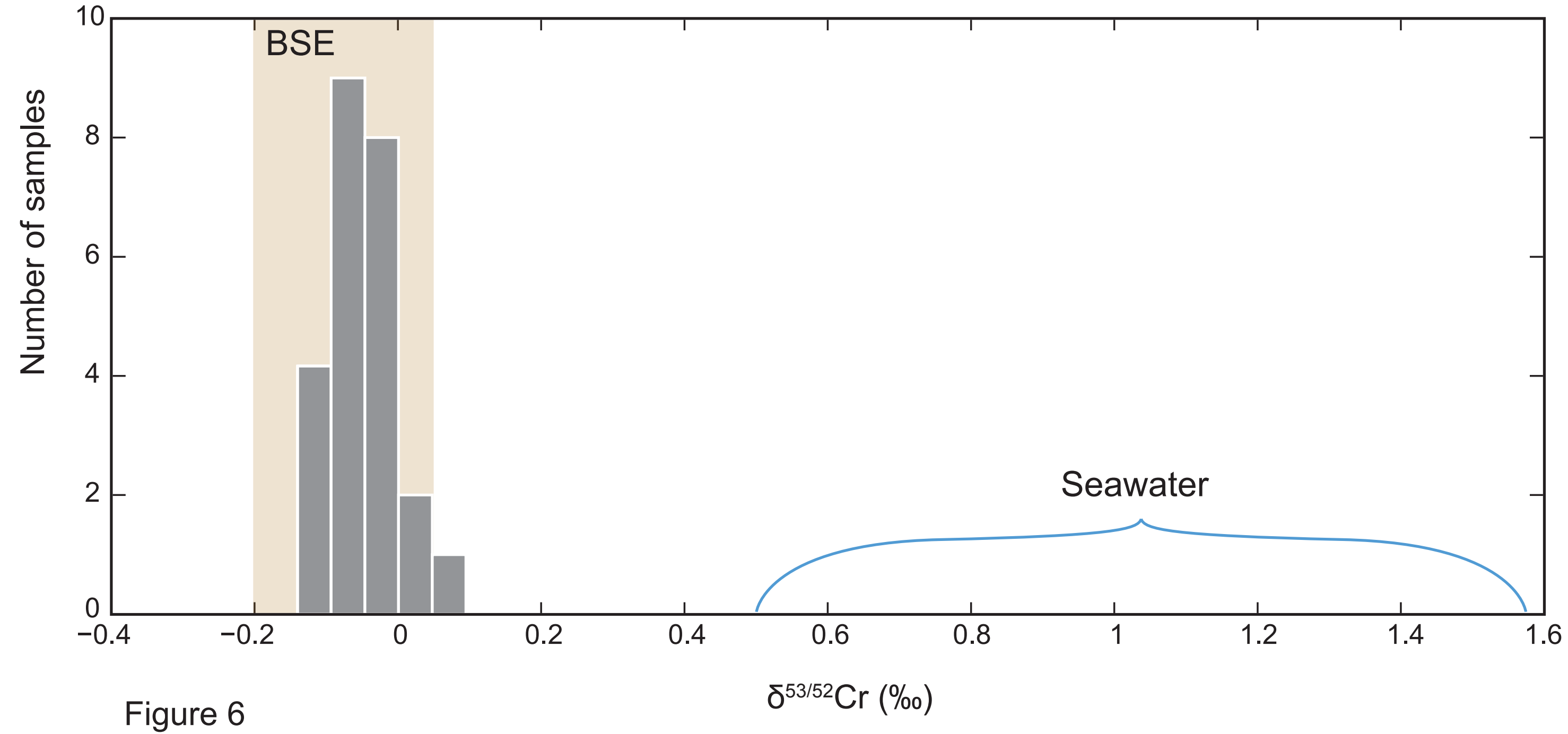

Figure 6

(\%o) 